\title{
A igreja Matriz de Santa Luzia e seus retábulos
}

The Mother's Church of Santa Luzia and its retables

http://dx.doi.org/10.1590/1982-02672019v27e14

\author{
AZIZ JOSÉ DE OLIVEIRA PEDROSA' \\ https://orcid.org/0000-0003-4274-1096 \\ Universidade do Estado de Minas Gerais / Belo Horizonte, MG, Brasil
}

RESUMO: A igreja Matriz de Santa Luzia, localizada na cidade mineira homônima, abriga em seu interior conjunto de retábulos que ainda não foram devidamente analisados pela historiografia da arte, apesar de se tratar de peças de significativa importância para 0 contexto da talha setecentista luso-brasileira. Diante das sombras que repousam sobre o tema, este artigo tem como orientação elementar o estudo de três retábulos do referido templo, em prol de conhecer os aspectos históricos e estilísticos que nortearam sua produção, bem como suas prováveis relações com outros exemplares congêneres encontrados em Minas Gerais.

PALAVRAS-CHAVE: Matriz de Santa Luzia. Retábulos. Século XVIII. Minas Gerais.

ABSTRACT: The Santa Luzia Mother's Church, in the city of Santa Luzia, holds a group of retables which wasn't duly analyzed in the context of Art History. Despite being significantly important to Luso-Brazilian carving of the 18th century. In view of the questions that arise on the topic, the present article aims to study three retables of said Church, with the intention of knowing the historic and stylistic aspects which influenced its production, as well as the relationship to other sister retables found in Minas Gerais.

KEYWORDS: Santa Luzia Mother's Church. Retables. 18th century. Minas Gerais.
1. Bacharel em Designer, especialista em História e Cultura da Arte, mestre e doutor em Arquitetura e Urbanismo. É professor de História da Arte na Universidade do Estado de Minas Gerais e Residente Pós-doutoral na Universidade Federal de Minas Gerais. E-mail: <azizpedrosa@ yahoo.com.br> 
2. Tavares (1975, p. 85$)$.

3. Mateus (2016, p. 57).

\section{INTRODUÇÃO}

A narrativa histórica da igreja Matriz de Santa Luzia, situada na cidade homônima, é permeada por ausências de difícil preenchimento, posto que a documentação testemunha de sua história está ausente dos arquivos paroquiais e, até o momento, não foi identificada em outros centros de pesquisa. Essa omissão condiciona o desconhecimento de registros elementares que indicariam, caso existissem, datas e nomes dos artífices envolvidos na produção arquitetônica e na ornamentação interna da referida edificação, onde está alocado destacável conjunto de retábulos e de pinturas suscetíveis de ilustrar os estágios basilares da arte colonial na então capitania mineira.

Além disso, os hiatos não solucionados pela historiografia impedem que as obras de talha, alocadas no ambiente da matriz luziense, sejam compreendidas no âmbito da arte coeva. Considera-se, para essa premissa, a permanência de feições formais e plásticas que permitem relacioná-las a modelos constantes em outras edificações sacras, situadas em cidades vizinhas a Santa Luzia, suscetíveis de sinalizar encaminhamentos acerca de possíveis ascendências geradas pela movimentação de oficiais, presumíveis eixos disseminadores de arquétipos e direções formais que condicionaram a elaboração dos retábulos em evidência.

À vista desses enunciados, este artigo tem como orientação sistematizar os parcos vestígios históricos localizados que aludem à produção do retábulo-mor e de dois outros retábulos dedicados a São José e a Nossa Senhora do Rosário, pertencentes ao templo principal de Santa Luzia. Oportunamente, examinam-se os ornamentos incorporados a essas peças, a fim de observar suas vinculações aos demais espécimes mineiros; demonstra-se sua inserção no cenário artístico, frente à hipotética atuação de alguns oficiais; por último, relativiza-se se a conformação desses itens foi influenciada por peças erguidas em núcleos urbanos próximos, que exibem aspectos congêneres e habilitados a demonstrar a atuação de uma mesma oficina. Insta esclarecer que esse direcionamento é passível de ser empregado em estudo inicial sobre os objetos retabulares em pauta, que ainda não foram avaliados, potencializando a construção de entendimentos habilitados a fundamentar pesquisas posteriores que tenham como cerne a avaliação crítica dessas amostras enfatizadas neste texto.

Subsidiando-se nessas orientações, nota-se que os raros registros históricos encontrados atestam que o atual templo dedicado a Santa Luzia foi reconstruído a partir de 1744, com o intuito de sediar as atividades cabíveis a uma igreja matriz, ${ }^{2}$ em substituição à primitiva capela erguida entre 1721 e 1729. ${ }^{3}$ Apura-se, conforme documentação disponível nos arquivos do Instituto Estadual do Patrimônio Histórico 
e Artístico de Minas Gerais (lepha), que as obras de construção estavam concluídas em 1778, pois no dia 13 de dezembro do mesmo ano ocorreu a bênção oficial da nova edificação. ${ }^{4}$ Com efeito, as atividades religiosas nesse espaço tiveram início após o dia 29 de fevereiro de 1780, quando foi realizada a trasladação solene do Santíssimo Sacramento de Roça Grande para a cidade de Santa Luzia. ${ }^{5}$ Sequencialmente, no correr dos séculos XIX e XX, reformas no edifício promoveram a modificação da fachada setecentista.

Em relação à ornamentação interna do templo, especificamente os retábulos, pontos de interesse deste texto, pouco se conhece, pois também são inexistentes os documentos que formalizaram o processo de produção dessas peças. ${ }^{6}$ Contudo, sobrevive a esperança de pesquisas futuras localizarem em arquivos brasileiros, ou até mesmo portugueses, elementos que possam esclarecer o processo histórico que embasou a fatura da talha e das belas pinturas que se encontram no interior da igreja matriz luziense.

Dentro dessas perspectivas, memora-se que parcos apontamentos a respeito do discurso histórico que delineou o ciclo de ornamentação da Matriz de Santa Luzia foram relatados pelo Cônego Raimundo Trindade ao anunciar a presença do retábulo-mor na dita edificação no ano de 1773: "O altar-mor da Matriz de Santa Luzia foi privilegiado in perpetuum por Breve de Clemente XIV de 15 de setembro de 1773, placitado a 19 de outubro do mesmo ano."7

Posteriormente, Tibúrcio de Oliveira, em 1956, emitiu nota referente à fábrica dos motivos escultóricos e retábulos que ornam o espaço sacro do templo luziense: "Pacheco Ribeiro contratou os serviços de moldura e de talhe com Felipe Vieira e com Francisco de Lima Cerqueira, que de 1760 a 1776 encheram de glória a arte decorativa de nossa terra. ${ }^{8}$ Essa menção evidencia a operação de Felipe Vieira e Francisco de Lima Cerqueira como os oficiais envolvidos na fábrica de talha para a edificação. No entanto, lamenta-se que Oliveira não tenha discriminado a fonte que embasou suas direções, tampouco detalhado as obras às quais se referiu. Embora esteja distante o encontro de respostas concretas para o caso, acredita-se que ele possa ter consultado fontes primárias paroquiais remanescentes dos setecentos, hoje inexistentes. Tal ideia está alicerçada no fato de que ainda não foram constatadas outras bases que permitissem mapear a atuação dos artífices supracitados, de forma a comprovar o enunciado de Tibúrcio de Oliveira.

Acrescenta-se que, no tangente à presumida intervenção de artistas nas tarefas destinadas a ornamentar a Matriz de Santa Luzia, é imperioso recordar a notícia de que Antônio Francisco Lisboa, o Aleijadinho, esteve em atividade na região de Santa Luzia. Essa informação veio a público no escrito publicado em 1858, por Rodrigo
4. Tavares (1975, p. 85).

5. Ibid., p. 85.

6. Para efetivação da pesquisa que encabeça este artigo, foram empreendidas buscas em arquivos localizados em cidades mineiras. Todavia, essa atividade se mostrou infrutífera, pois no destacável Arquivo da Cúria de Mariana, que abriga dados sobre as igrejas de $\mathrm{Mi}$ nas Gerais, nada foi localizado. Apenas nos arquivos do Instituto do Patrimônio Histórico e Artístico Nacional (IPHAN) e do Instituto Estadual do Patrimônio Histórico e Artístico de Minas Gerais (IEPHA) foi possível identificar algumas informações acerca do tema.

7. Trindade (1945, p. 269).

8. Oliveira (1956, p. 2). 
9. Cf. Ministério da Educação... (1951).

10. Ibid., p. 32.

11. Tavares (1975, p. 87).

12. Oliveira (1956, p. 2).
José Ferreira Bretas, em que o autor organizou a primeira biografia sobre o artífice. ${ }^{9}$ Escreveu Bretas que o Aleijadinho "exerceu sua arte" em algum templo luziense, ${ }^{10}$ sem, no entanto, especificar a igreja, o trabalho empreendido e o período em que foi executado. As dificuldades de avaliar esse apontamento são acentuadas perante a inexistência de documentação que legitime a suposta intervenção do nobre artista e, do mesmo modo, especifique o local onde ele possa ter deixado sua arte: se na matriz ou se em alguma outra edificação religiosa no entorno do então povoado.

Em benefício de esclarecer as incertezas que delineiam a matéria, ancorada nos escritos de Rodrigo José Ferreira Bretas, a pesquisadora Myriam Ribeiro da Silva Tavares, ao elaborar estudos destinados à promoção do tombamento do templo pelo lepha, elencou a possibilidade do Aleijadinho ter colaborado na fatura de elementos de talha constantes no retábulo-mor da Matriz de Santa Luzia.

A colaboração do Aleijadinho na talha deste retábulo é hipótese que poderia eventualmente ser levada em consideração, partindo-se da premissa que Santa Luzia figura na relação de localidades onde o artista teria "exercido sua arte", levantada por Rodrigo José Ferreira Bretas em 1858. Tratar-se-ia neste caso de um de seus primeiros trabalhos, quando ainda aprendiz, sob orientação de um mestre cujo nome infelizmente ainda ignoramos (o medaIhão de Nossa Senhora, à esquerda, apresenta relação com o estilo pessoal, sobretudo no rosto e nas mãos). ${ }^{11}$

A proposição do envolvimento do Aleijadinho na produção do retábulo-mor, levantada por Myriam Ribeiro da Silva Tavares, é conteúdo permeado de indefiniç̧̃̃es, principalmente porque são insuficientes as feições plásticas constantes na obra, bem como os vestígios documentais qualificados a mapear o labor do artista na fábrica de relevos escultóricos arranjados no objeto retabular. Do mesmo modo, acerca da suspeita aventada de que o Aleijadinho, na igreja Matriz de Santa Luzia, laborou sob a orientação de algum supervisor, cabe frisar que essa é uma proposição de difícil esclarecimento, pois não admite a interposição de prováveis soluções para deslindá-la, o que seria possível somente diante da existência de suporte documental, capaz de precisar minúcias referentes ao caso. Todavia, tendo em vista os assentamentos redigidos por Tibúrcio de Oliveira, ${ }^{12}$ de que Felipe Vieira e Francisco de Lima Cerqueira estiveram em atividade no referido templo, poder-se-ia suspeitar que um desses homens foi o preceptor de Antônio Francisco Lisboa. Essas sugestões intentam, unicamente, estabelecer interpretações a respeito das ideias propagadas pelos autores em debate, insuficientemente exploradas. 
À vista dessas exposições, demonstraram-se os exíguos fragmentos que intentam aclarar trechos da história que sublinhou a construção dos retábulos da Matriz de Santa Luzia, representados pelo retábulo-mor e por dois outros retábulos que se encontram junto ao arco-cruzeiro, dedicados a Nossa Senhora do Rosário e a São José. Seguramente, essas são as obras mais antigas do edifício, associadas às influências do estilo joanino ${ }^{13}$ e Rococó, ${ }^{14}$ que especificaram as formas e as estruturas constantes na talha luso-brasileira, após os anos de 1730 até a virada para o século XIX.

\section{ANÁLISES}

Considerando-se o limitado conteúdo histórico referente aos retábulos da Matriz de Santa Luzia, compete ao pesquisador efetuar análises dos objetos de arte, para que se possam estabelecer conjecturas que intentem clarificar vestígios do provável momento em que foram produzidos, o modo como foram manuseadas as referências artísticas e estéticas correntes no âmbito artístico luso-brasileiro, e as eventuais relações que apresentam com seus pares.

Nesse sentido, no retábulo-mor do templo luziense, constata-se a presença de base com pinturas simulando marmorizado, tendência recorrente na policromia dos elementos arquitetônicos e ornamentais das igrejas mineiras em fins do século XVIII e início do XIX. ${ }^{15}$ Conforme Antônio Gilberto Costa, ${ }^{16}$ essa técnica foi empregada em substituição à exiguidade local de rochas apropriadas para revestir esses equipamentos (figura 1). Sequencialmente, o registro do banco compreende pares de mísulas laterais, compostas por cabecinhas de anjos, festões e palmetas; cartelas emolduradas por ornatos curvilíneos e vegetalistas; sacrário central com cortinado, cabecinhas de anjos, relevos de nuvens e motivos vegetalistas.

A sustentação da seção do corpo é assegurada por pares de colunas de tipologia salomônica com fustes cobertos por flores. No intercolúnio, há cabecinhas de anjos envolvidas em elementos curvilíneos, fitomórficos e arremate de palmeta. Destacam-se, nessa região, os medalhões centrais que envolvem os relevos de Nossa Senhora (esquerda) e de São José (direita). Esses itens substituíram os nichos tradicionalmente integrados aos retábulos setecentistas lusobrasileiros, entre colunas ou ladeando o camarim, como bem ilustram os retábulos do arco-cruzeiro da igreja Matriz de São Caetano (Monsenhor Horta). O camarim compreende o trono escalonado em degraus de diferentes formatos, teto em abóbada de berço, paredes recobertas por talha e festões de flores ao fundo.
13. Para Robert Smith (1962), o "estilo joanino" abarca as produções artísticas lusófonas, ocorridas ao longo da primeira metade do século XVIII, abrangendo, aproximadamente, o intervalo coincidente ao reinado de Dom João $\mathrm{V}$ (1706-1750). A terminologia empregada pelo autor especifica o período em que a arte e a arquitetura portuguesa refletiram referências barrocas, sobretudo as italianas, provenientes da circulação de publicações, objetos, artistas e arquitetos que impulsionaram desdobramentos para o contexto cultural local. Ver Robert C. Smith (1962, p.95-114). Nesse sentido, será utilizada, neste artigo, a nomenclatura "estilo joanino" para se referir aos exemplares luso-brasileiros que repercutiram a ascendência da arte reinol coeva, a partir da década de 1720 .

14. Segundo a pesquisadora Myriam de Oliveira (2003), a década de 1730 assinalou as primeiras manifestações do Rococó na França. Nesse período, surgiram os trabalhos de artistas ornamentistas, destacando-se os nomes de Juste - Aurèle Meissonnier (1695-1750), Nicolas Pineau (1684-1754) e Jacques de Lajoue (16861761). Memora a autora que, inicialmente vinculado às artes ornamentais francesas, o Rococó foi referência para a talha luso-brasileira, empregado na decoração interna dos templos coloniais, a partir do ano de 1753, quando foi iniciada a confecção do retábulo-mor da igreja de Santa Rita, no Rio de Janeiro - Oliveira (2003, p. 28-183).

15. Ávila; Gontijo; Machado (1996, p. 157).

16. Costa (2009, p. 291). 


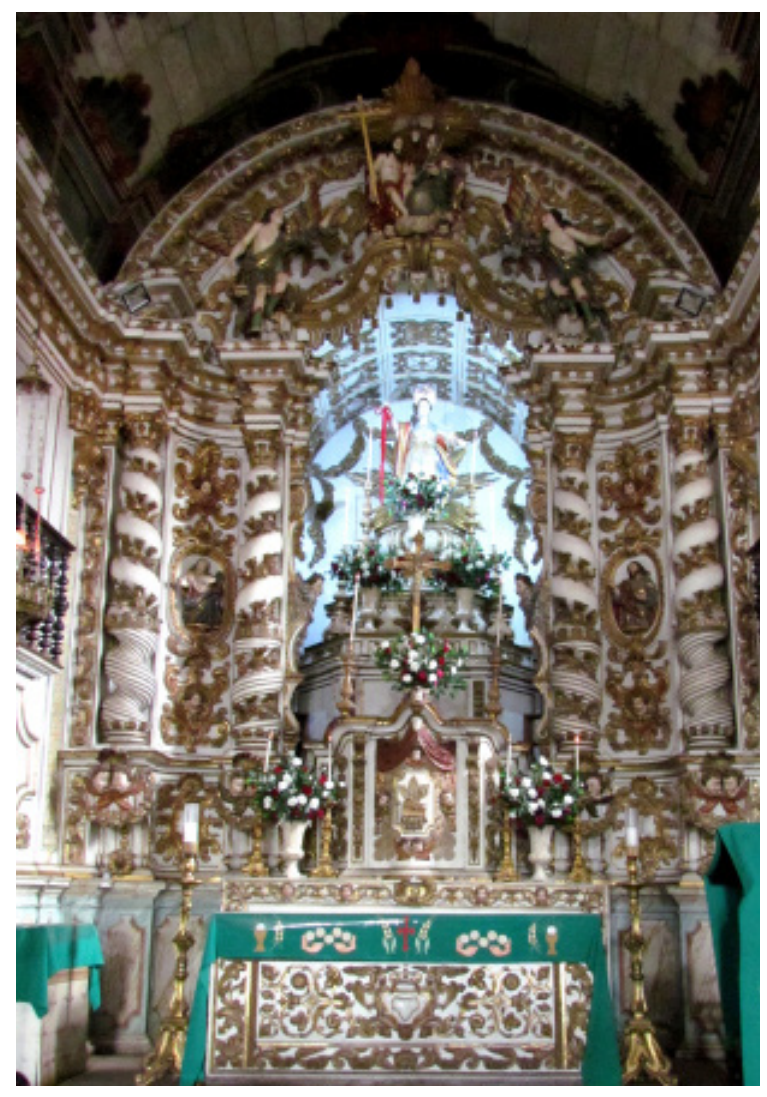

Figura 1 - Retábulo-mor da igreja Matriz de Santa Luzia, Santa Luzia (2017). Fotografia do autor.

Arrematam o coroamento fragmentos de frontões curvos, posicionados na continuação das colunas de tipologia salomônica externas. Internamente, mísulas triplas sustentam figuras antropomórficas aladas que reverenciam o relevo central da Santíssima Trindade, integrado pelo Deus Pai com o cajado, o Filho segurando a Cruz, o globo representando o mundo recém-criado e a pomba símbolo do Espírito Santo. Finalizam o registro um dossel arqueado com lambrequins, motivos em forma de "C", itens fitomórficos e enrolamentos.

Apura-se que o retábulo-mor da matriz luziense pronuncia feições estruturais e formais alusivas à arte da talha joanina, que em Minas Gerais inspirou a produção retabular entre os anos 1730 e 1760, como esclarece a pesquisa publicada por Aziz José de Oliveira Pedrosa. ${ }^{17}$ São concernentes a esse ciclo: os pares de colunas de tipologia salomônica, o dossel contracurvado, as figuras antropomórficas de vulto no coroamento, incluindo-se o grupo da Santíssima Trindade, presente em diversos 
exemplares luso-brasileiros do período, como atesta o retábulo-mor da igreja Matriz de Nossa Senhora do Pilar (Ouro Preto), os fragmentos de frontões curvos, as mísulas e o delineamento de uma composição retabular de aspecto arquitetônico, acentuada pela fundamental permanência desses e de outros elementos extraídos do âmbito da arquitetura. Esses exemplares concorrem para edificar e simular o senso de espacialidade, por meio de construções tridimensionais integradas, transformando o ambiente em que se encontram em uma conformação de sucessivos e distintos planos coordenados por relevos definidores do plano retabular.

É presumível que a permanência de feições arquitetônicas na modelação dos retábulos mineiros esteja atrelada ao aprendizado obtido pelos artífices, em momento anterior à vinda para a Colônia brasileira, bem como ao conhecimento extraído de fontes impressas que circularam na Capitania de Minas Gerais. A primeira sugestão é de difícil argumentação, uma vez que seria imprescindível conhecer a formação do mestre responsável pela traça do retábulo-mor da matriz luziense para a sua exposição. Todavia, o segundo pressuposto é alicerçado em estudos que sinalizaram a presença de livros de arquitetura e de gravuras de ornamentação que figuram entre os bens materiais pertencentes aos homens que se dedicavam a construir e a ornar os templos religiosos locais.

Nesse âmbito, Ivo Porto de Menezes atestou que o carpinteiro Manuel Francisco de Araújo foi possuidor de "um livro de arquitetura", ${ }^{18}$ cujo registro prenunciador não designa esclarecimentos acerca da autoria e do título da peça. Por sua vez, as pesquisas de Camila Santiago especificaram que o pintor Caetano Luís de Miranda, executor de trabalhos pictóricos na região do Serro, a partir das últimas décadas do século XVIII, foi detentor de notável quantidade de impressos, em que constavam dois itens, denominados Prespectivas dos pintores in follio dois volumes, ${ }^{19}$ que, segundo a autora, podem ser os tratados do irmão jesuíta Andrea Pozzo, e Perspectiva Pictorum et Architectorum, publicados em Roma, entre os anos de 1693 e 1700.20

Entrelaçam-se a esse quadro os resultados das investigações de Mateus Alves Silva, em que se especificam a permanência dos tratados de Andrea Pozzo nas Minas setecentistas, catalogados em fichas constantes na biblioteca do Santuário do Caraça (Minas Gerais). Lamentavelmente, os aludidos livros não foram localizados pelo sobredito autor. ${ }^{21}$ Ademais, Aziz José de Oliveira Pedrosa identificou, entre os bens arrolados no inventário do entalhador lisboeta José Coelho de Noronha, ativo na capitania mineira entre os anos de 1740 e 1765, relevante lista de livros em que constava um volume de "estampas que serviam de arquitetura" e "dois livros de arquitetura, primeira e segunda parte". ${ }^{22}$ Apoiado no exame da obra faturada pelo
18. Menezes (1978, p. 100).

19. Santiago (2009, p. 153).

20. Cf. Pozzo (MDCCLVIII).

21. Silva (2012, p. 76).

22. Pedrosa (2012, p. 269). 
23. Id. (2018, p. 107).

24. Constatam-se feições congêneres, balizando a configuração dos retábulos-mores das igrejas Matrizes de Nossa Senhora do Pilar (1755 - 1758, São João del-Rei, Minas Gerais) e de Nossa Senhora do Bom Sucesso (1758 - 1763, Caeté, Minas Gerais), ambos elevados pelo entalhador José Coelho de Noronha e sua oficina.

25. Pozzo (MDCCLVIII, figura 62).

26. Pedrosa (2016, 453).

27. Pozzo (MDCCLVIII, figura 60).

28. Pedrosa (2016). referenciado oficial, o pesquisador considerou a viabilidade de esses dois últimos exemplares serem os tratados de Andrea Pozzo. ${ }^{23}$ Em vista dessas ocorrências, conquanto não foram encontradas as publicações declaradas, compreende-se que em Minas Gerais elas estiveram presentes, servindo para referenciar elementos que compuseram a ornamentação e a arquitetura religiosa do período.

No tocante ao retábulo-mor da Matriz de Santa Luzia, é admissível identificar a repercussão de arquétipos que, eventualmente, podem ter sido referenciados em figuras constantes nos tratados de Andrea Pozzo, ou em conjuntos retabulares mineiros que recorreram aos elementos divulgados por essas imagens, em proveito de definir seu arranjo formal. Esse juízo é fundamentado na composição dos pares de colunas de tipologia salomônica e no delineamento arquitetônico do entablamento do retábulo-mor luziense em estudo, ${ }^{24}$ que apresenta relações com os itens ilustrados (figuras 6 e 2 ) na referida publicação pozziana. ${ }^{25}$ Esse mesmo desenho, constante no trabalho do Pozzo, apresenta intercolúnios desprovidos de nichos, tal qual a obra em evidência, distinguindo-se de outros modelos locais em que esses aparatos se tornaram gerais, desde a década de 1730, quando o lisboeta Manuel de Brito emendou a fatura de peças retabulares para a igreja Matriz de Nossa Senhora do Pilar (Ouro Preto). ${ }^{26}$

Outras correspondências entre as ilustrações constantes nos volumes do tratado do Pozzo e o retábulo-mor da Matriz de Santa Luzia são percebidas na representação do grupo escultórico da Santíssima Trindade, exibido no projeto para o Altare de S. Ignatio (figura 6), concebida pelo referenciado tratadista. ${ }^{27}$ Verifica-se a presença dessa alegoria em diversos espécimes retabulares mineiros, como no retábulo-mor da igreja Matriz de Nossa Senhora da Conceição /Catas Altas, $1746-1759$ ) 28 $^{28}$ no antigo retábulo-mor da Matriz de Santo Antônio (Santa Bárbara, 1744), cujos fragmentos constituem o acervo do Museu da Inconfidência (Ouro Preto). Logo, é presumível que a sugestão para o uso dessa referência esteja entrelaçada à difusão dos desenhos de Andrea Pozzo na Capitania de Minas, tal como à disseminação do repertório formal e iconográfico que permeou o universo da escultura religiosa no ambiente artístico luso-brasileiro setecentista.

A percepção de que há equivalências formais e estruturais entre o retábulo-mor do templo de Santa Luzia e o supramencionado tratado de Andrea Pozzo asseveram referências elaboradas no continente europeu, cintilando na talha faturada para ornar os templos setecentistas de Minas Gerais. Apesar desse senso, não é acertado atestar se essas repercussões resultaram da consulta direta desses livros, pelo mestre que elaborou o desenho para a obra luziense, ou se decorreram da observação de afamadas peças de talha 
produzidas à época, que podem ter instigado o imaginário do artífice que gizou o conjunto em estudo, como será oportunamente detalhado neste texto.

Ademais, desses apuramentos, entende-se que no retábulo-mor da Matriz de Santa Luzia também foram anexados motivos frequentes à talha rococó, tais como relevos curvos, sinuosos, assimétricos e duplas cabecinhas de anjos, recordando que essas últimas foram populares nas obras faturadas pelo entalhador Francisco Vieira Servas, como se verifica no retábulo-mor da igreja de Nossa Senhora do Carmo (Sabará 1806 - 1809). ${ }^{29}$ Do mesmo modo, atrelado às feições do Rococó, está o pronunciamento da pintura de fundo branco que evidencia ornatos dourados. Por esse entendimento, reconhece-se que a traça do retábulo-mor da Matriz de Santa Luzia contemplou a inserção de caracteres afeiçoados ao estilo joanino, conjugados às novidades francesas que emergiam na ornamentação interna das igrejas de Minas, por volta de 1760, principalmente a partir da elevação dos retábulos instalados na nave da igreja Matriz de Nossa Senhora do Bom Sucesso (Caeté), onde floresceu a plástica que conformaria a ornamentação dos templos mineiros até as primeiras décadas do século XIX, como relativizado nas pesquisas elaboradas por Myriam Oliveira. ${ }^{30}$

As ponderações arroladas outorgam deliberar que o retábulo-mor da Matriz de Santa Luzia preserva relações formais e estéticas com outros modelos mineiros coetâneos, representados pelos retábulos-mores das igrejas Matriz de Nossa Senhora da Conceição (Catas Altas, 1746 - 1752), Matriz de Nossa Senhora do Pilar (Ouro Preto, 1746 - 1754), Matriz de Nossa Senhora do Pilar (São João del-Rei, 1755 - 1758) e Matriz de Nossa Senhora do Bom Sucesso (Caeté, 1758 - 1763).

A validação dessas interposições pode ser averiguada no retábulo-mor da igreja Matriz de Nossa Senhora da Conceição (Catas Altas), elevado a partir do ano 1746 pelo entalhador Manoel Gonçalves Valente e os membros da oficina envolvidos na execução do serviço arrematado. ${ }^{31}$ Observa-se que as afinidades entre essa peça retabular e o retábulo-mor da Matriz de Santa Luzia são detectadas no uso de mísulas do banco, nas colunas de tipologia salomônica e no intercolúnio adornado com motivos curvilíneos, cabeças de anjos e palmetas. No coroamento, itens correspondentes são encontrados no interessante dossel sinuoso com lambrequins e na presença do grupo escultórico da Santíssima Trindade.

Por sua vez, cumpre deliberar sobre o retábulo-mor da matriz ouropretana de Nossa Senhora do Pilar, riscado por Francisco Branco de Barros Barrigua em 1745-1746 32 e, posteriormente, modificado pelo entalhador Francisco Xavier de Brito, incumbido da execução juntamente com seu então sócio Antônio Henriques Cardoso. ${ }^{33}$ A documentação ilustra que a produção
29. Martins (1974, vol. 2, p. 216).

30. Oliveira (2003, p. 251).

31. Martins (1974, vol. 2, p. 294).

32. Arquivo da Paróquia... (1729-1777, vol. 224, fl. 34).

33. Ibid. (1729-1777, vol. 224, fl. 61v). 
dessa peça se prolongou até por volta de 1754, quando o entalhador lisboeta José Coelho de Noronha emendou ajustes na obra. Salvo o complexo contexto histórico que norteou todo esse trabalho, computam-se correspondências plásticas entre ele e o retábulo principal da Matriz de Santa Luzia. Tais relações servem como indícios de que ambas as peças tiveram suas histórias entrelaçadas, sendo que a de Ouro Preto pode ter servido de inspiração para o desenho da outra, embora não se possa validar a intervenção de um mesmo grupo de oficiais envolvidos na confecção dessas obras, tampouco precisar a data exata em que ocorreu a fábrica do modelo luziense. Ratifica tal interposição empreendida a presença de similar organização estrutural e composicional desses retábulos, definida pelas colunas de tipologia salomônica, camarim em profundidade, renda da boca da tribuna, e de uma análoga feição do coroamento, com suas formas, ornatos e, principalmente, a alegoria da Santíssima Trindade que ilustram, devidamente, as indicações proferidas.

É inteligível que frações das soluções plásticas inclusas no retábulo-mor da Matriz de Santa Luzia podem ter sido referenciadas nas obras enumeradas, em outro contexto temporal e artístico, no qual o Rococó exercia pujante ascendência. A razoabilidade dessa ideia é embasada no conhecimento de que foi intensa a circulação de artistas no território das Minas setecentistas, em função das oportunidades de trabalho que condicionavam a presença desses homens em um amplo espaço geográfico, permitindo-thes conhecer a arte de seus pares, nela se inspirar e dela extrair referências passíveis de serem incorporadas ao repertório gráfico e às obras que empreenderiam em sequência.

Além disso, estimar as familiaridades que medeiam esses modelos possibilita estipular a provável data em que foi realizada a obra do retábulo-mor da igreja Matriz de Santa Luzia, considerando-se para essa analogia os períodos que balizaram a elevação dos retábulos dos templos supracitados. Assim, é aceitável que esse exemplar luziense possa ter sido fabricado na década de 1760 e princípios de 1770 . Esteia essa assertiva o conhecimento de que, em 1773, a dita peça retabular se encontrava concluída, conforme relatado por Cônego Raimundo Trindade. ${ }^{34}$ Acrescentam-se aos preceitos fundamentadores dessa conjectura certas afinidades pontuadas nesse retábulomor e em outros incorporados às edificações sacras mineiras, talhados por volta de 1750, cujas feições plásticas engendram semelhanças qualificadas a reforçar os enunciados pronunciados. 
Entre os modelos habilitados a validar essas possíveis influências, enumeram-se os retábulos-mores da Matriz de Nossa Senhora do Pilar (São João del-Rei) ${ }^{35}$ e da Matriz de Nossa Senhora do Bom Sucesso (Caeté), executados pelo entalhador José Coelho de Noronha e a oficina por ele coordenada. Foi ro... (códice 1075). por intermédio da materialização dessas obras que as peças retabulares joaninas mineiras vislumbraram diferentes estruturação e emprego de motivos ornamentais, não encontrados nos modelos congêneres locais erguidos entre as décadas de 1730 e 1750. Esclarecem essas interposições as mísulas do banco com cabecinhas de anjos, igualmente pontuadas no retábulo principal da Matriz de Santa Luzia, que substituíram as figuras antropomórficas de atlantes, tradicionalmente aplicadas nesses elementos, como identificado no retábulo-mor da igreja Matriz de Nossa Senhora do Pilar (Ouro Preto).

A composição do registro do corpo da peça retabular luziense também alude aos retábulos-mores das matrizes de São João del-Rei e Caeté, onde estão concretizados homônimo emprego de pares de colunas de tipologia salomônica, abordagem característica das preferências que nortearam os trabalhos de Coelho de Noronha, ${ }^{36}$ ausentes em exemplares coevos como declaram os retábulos-mores das igrejas Matriz de Nossa Senhora da Conceição (Catas Altas) e Matriz de Nossa Senhora do Pilar (Ouro Preto), que receberam apenas uma coluna em cada tramo associada ao quartelão. É necessário salientar que, a partir dos retábulomores das supracitadas igrejas matrizes ouro-pretana e catas-altense, podem ter sido extraídas sugestões para compor o retábulo-mor do templo de Santa Luiza, dada a permanência de certas correspondências constantes entre eles, avistadas no dossel arqueado com lambrequins, no modelo para o grupo da Santíssima Trindade, e até mesmo na direção para a organização dos registros e tramos que seguem equivalente orientação nos três espécimes retabulares arrolados, seguramente resultantes das influências plásticas da talha do período.

Essa suposição é alicerçada no conhecimento de que a circulação de artistas entre as principais vilas da Capitania de Minas, durante o século XVIII, foi um dos fatores condicionantes para a configuração formal e estilística dos retábulos, divulgadores do conhecimento propagado por núcleos de trabalho responsáveis pela fatura desses itens. Através dessas perspectivas, pode ser examinada a composição do retábulo-mor da Matriz de Santa Luzia, que não omite determinadas vinculações aos exemplares analisados, viabilizando emergir a percepção de que referências extraídas dessas obras podem ter contribuído para a elaboração de sua traça. 


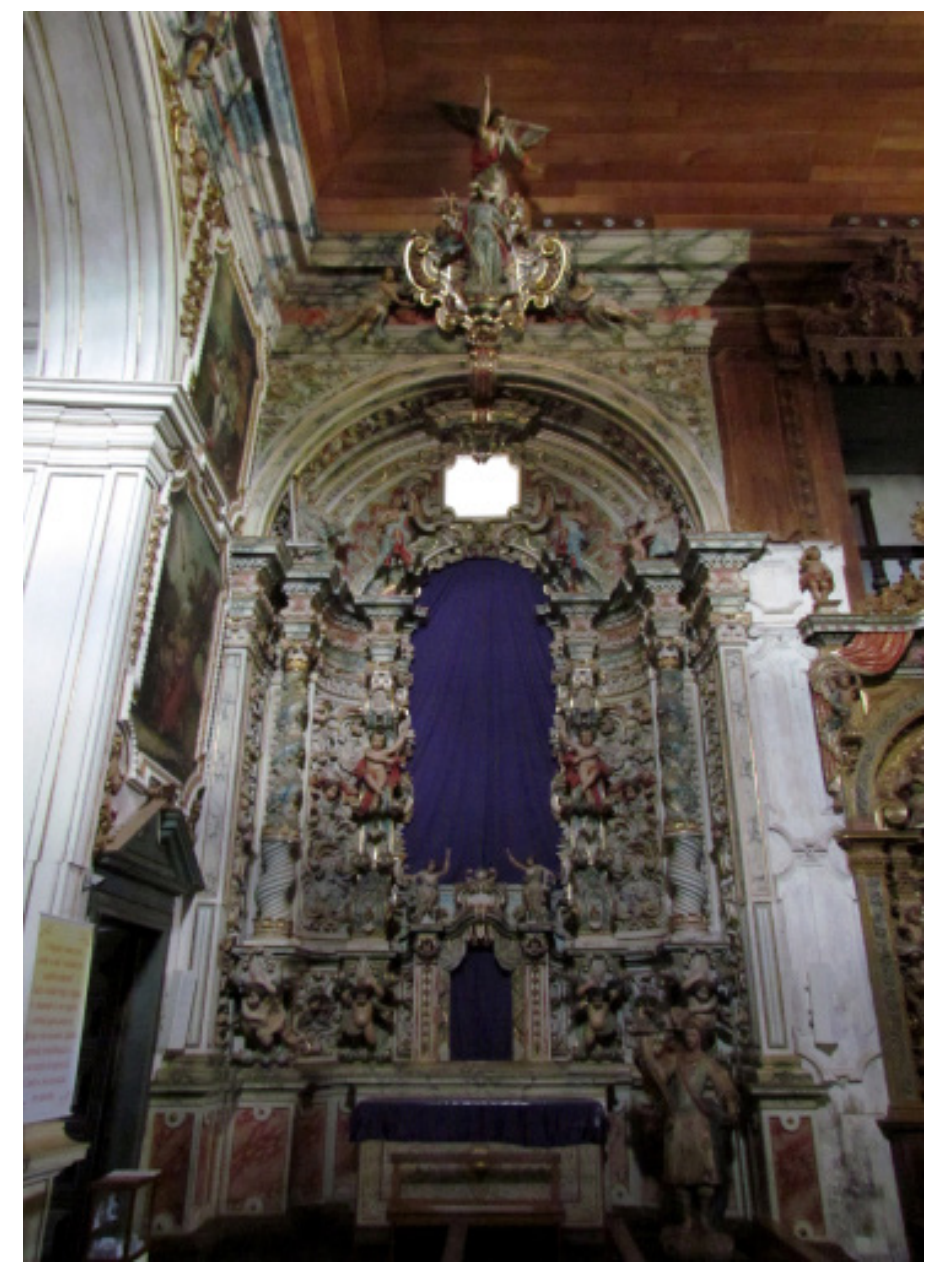

Figura 2 - Retábulo de São Miguel, igreja Matriz de Nossa Senhora da Conceição, Catas Altas (2018). Fotografia do autor.

Por esse ângulo, também é admissível ponderar que alguns elementos constituidores do retábulo-mor da Matriz de Santa Luzia estão diretamente atrelados ao labor de outro entalhador ativo em Minas Gerais, responsável pela execução das esculturas que preenchem o retábulo de São Miguel da igreja Matriz de Nossa Senhora da Conceição (Catas Altas). Essa premissa autoriza embasar os apontamentos de que a ornamentação de peças pertencentes ao templo catasaltense pode ter servido como fonte de referência para a configuração estética do retábulo principal luziense, a partir do trânsito de oficiais em atividade em ambas as edificações, agentes responsáveis por esse intercâmbio de ideias. 
Tal assertiva é ancorada na surpreendente semelhança existente entre as figuras antropomórficas instaladas nas mísulas do banco, quartelões, intercolúnios e outras seções do retábulo de São Miguel da Matriz de Catas Altas (figura 2), que são idênticas às cabecinhas de anjos que compõem a boca da tribuna e as mísulas do banco do retábulo-mor da Matriz de Santa Luzia (figuras 3 e 4). Comprova-se que as esculturas angelicais arroladas exibem proporcional desenho do queixo, dos lábios delineados e semiabertos, deixando aparente a dentição, das salientes bochechas, do nariz arrebitado em angulosidade retilínea na região das narinas, do relevo que promove a conexão da boca com o nariz, dos olhos arregalados, sobrancelha arqueada, do volume dos cabelos em cachos e da franja central que recai sobre a testa em pequeno filete (figuras 5 e 6). A constatação dessas equivalências sustenta a indicação de que o escultor envolvido na fatura das citadas imagens da igreja Matriz de Catas Altas foi também o autor das peças do retábulo principal da igreja luziense examinadas neste texło.

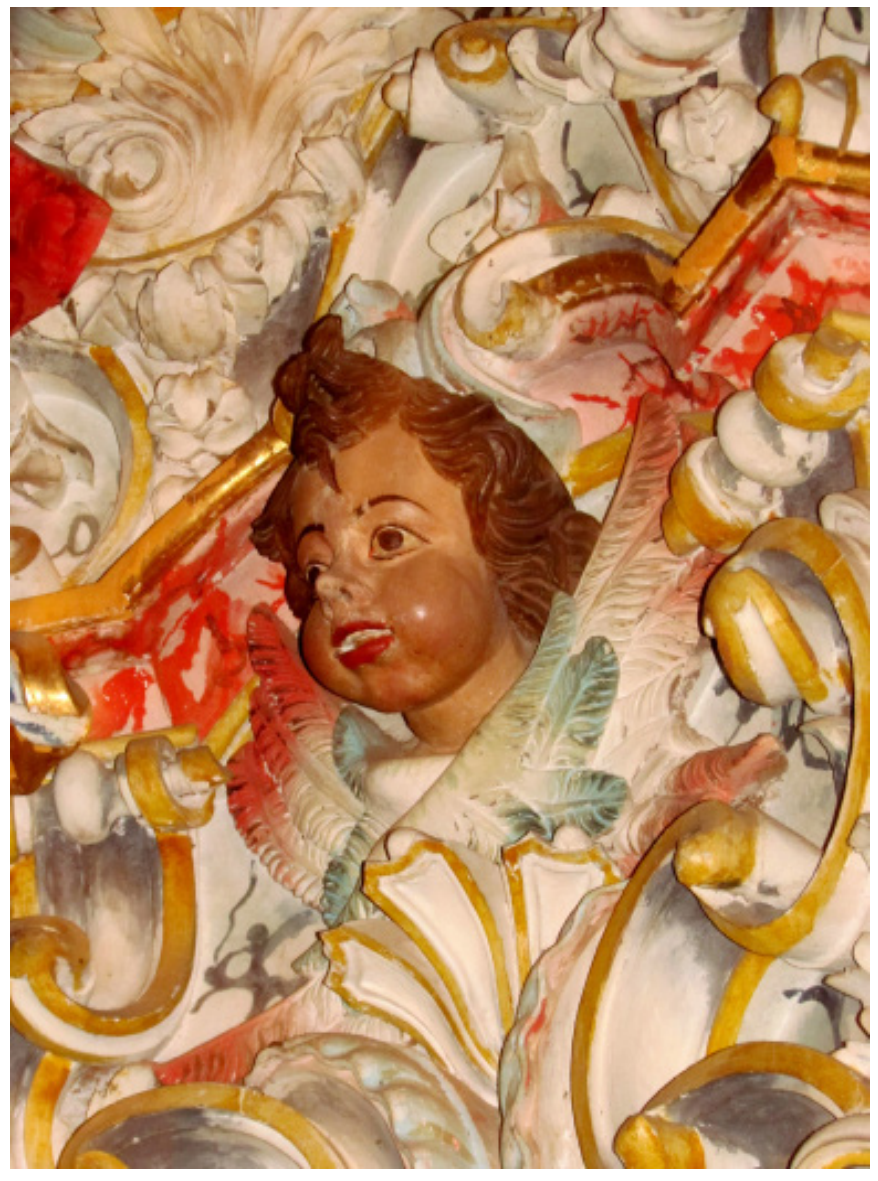

Figura 3 - Figura antropomórfica do retábulo de São Miguel e Almas, igreja Matriz de Nossa Senhora da Conceição, Catas Altas (2015). Fotografia do autor. 


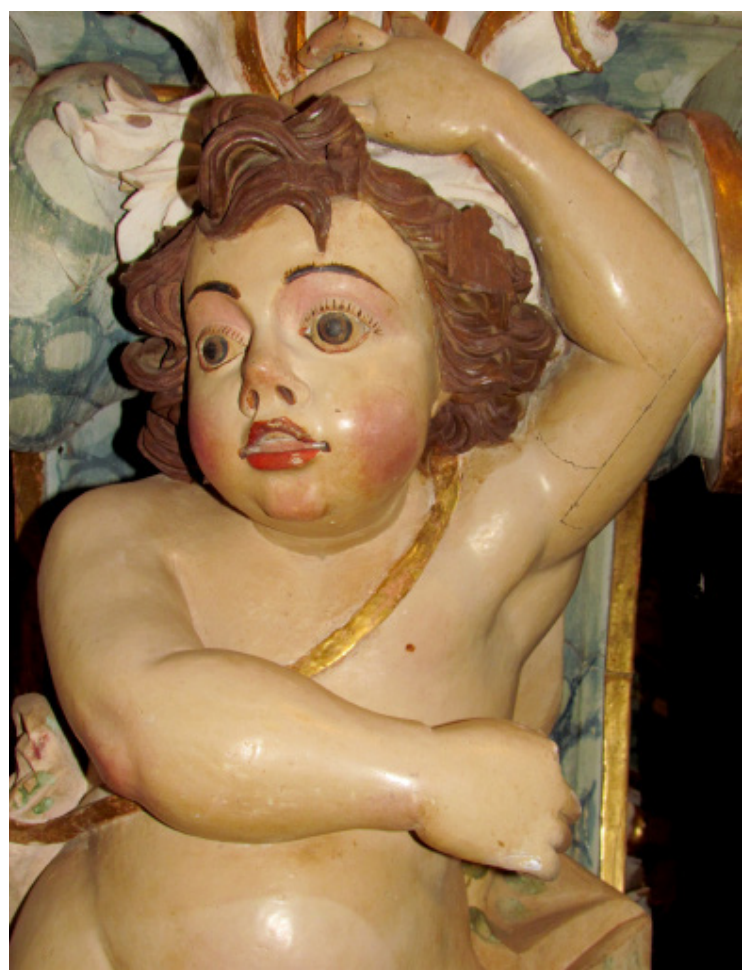

Figura 4 - Figura antropomórfica do retábulo de São Miguel e Almas, igreja Matriz de Nossa Senhora da Conceição, Catas Altas (2015). Fotografia do autor.

Figura 5 - Cabecinhas de anjos, retábulo-mor da Matriz de Santa Luzia, Santa Luzia (2017). Fotografia do autor.

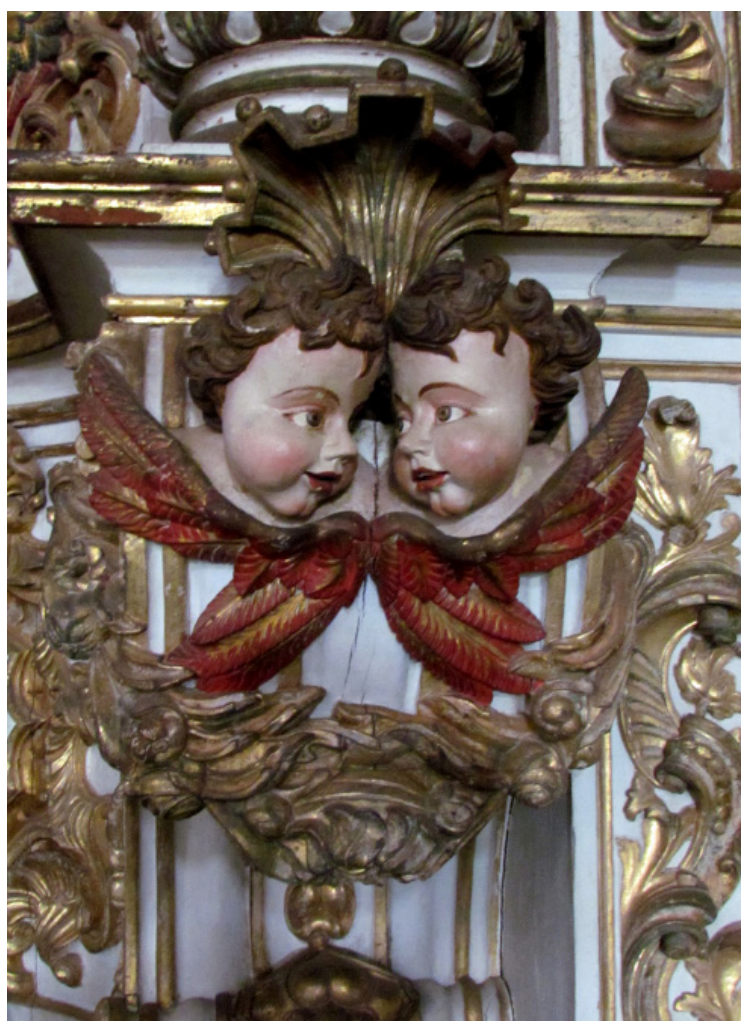




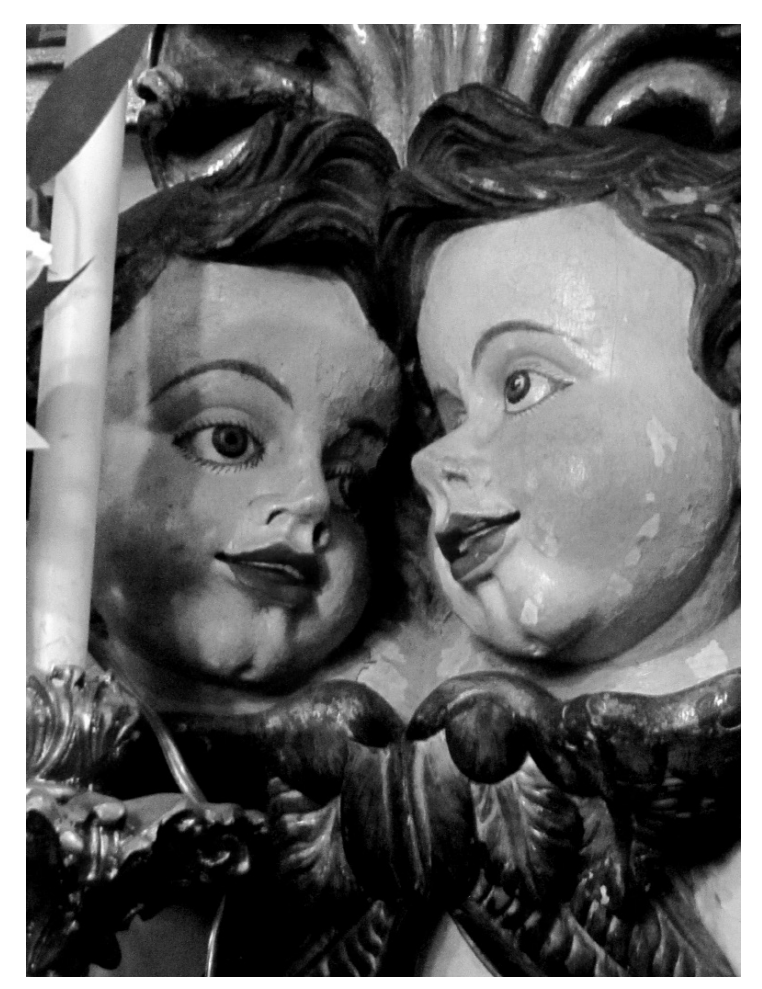

Figura 6 - Cabecinhas de anjos, retábulo-mor da Matriz de Santa Luzia, Santa Luzia (2017). Fotografia do autor.

Ademais, a alegoria da Santíssima Trindade e os anjos que dinamizam o coroamento do retábulo-mor da igreja Matriz de Santa Luzia também requerem ser analisados a partir do confronto com as imagens anexadas ao retábulo de São Miguel, que autorizam presumir se tratar de quocientes da atividade de um mesmo oficial (figura 7). Essa assertiva é fundamentada na permanência de feições formais congêneres existentes entre essas peças, delimitadas na anatomia do corpo, detalhes escultóricos da face, expressividade do olhar, delineamento das vestimentas, penteado dos cabelos, equivalente desenho dos olhos, nariz, boca e queixo. Soma-se a essas comprovações a constatação de que os anjos do retábulomor luziense são similares às esculturas do coroamento do exemplar de São Miguel, relevados tais aspectos nos análogos formatos dos olhos, sobrancelhas e penteado do cabelo partido ao meio e voltado para porção superior das costas. Esses indícios elucidam as hipóteses interpostas de que as figuras antropomórficas desses dois espécimes retabulares foram lavradas por um único artista. Entretanto, é importante registrar que as sobreditas imagens do templo de Catas Altas sinalizam a intervenção de outro artífice que, certamente, colaborou na execução de algum pormenor, embora seja desconhecida a sua identidade. 
37. Nos retábulos de Minas, os medalhões não foram de uso frequente até a década de 1770, que assinalou o período de produção do retábulo-mor da Matriz de Santa Luzia. Posteriormente, esses elementos se fizeram presentes em trabalhos do Aleijadinho, como no retábulo-mor da igreja ouro-pretana de São Francisco de Assis.

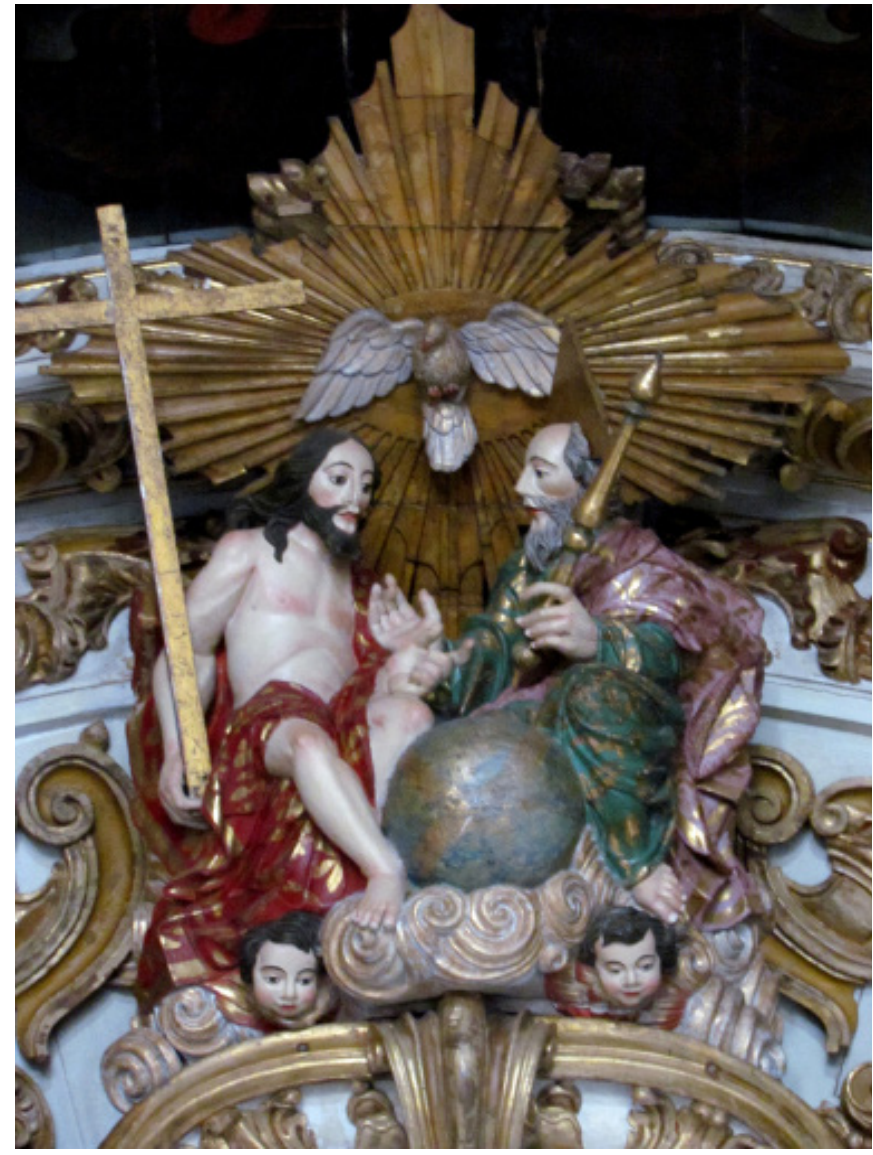

Figura 7 - Grupo escultórico Santíssima Trindade, retábulo-mor da Matriz de Santa Luzia, Santa Luzia (2017). Fotografia do autor.

Sequencialmente, vê-se no retábulo-mor da Matriz de Santa Luzia interessantes medalhões com relevos da Virgem Maria e São José, inseridos no intercolúnio (figuras 8 e 9), que particularizam a composição dessa obra retabular. A atípica presença desses elementos na talha mineira setecentista torna impreciso delimitar prováveis motivos que possam, eventualmente, justificar seu uso. ${ }^{37}$ No entanto, a primeira constatação que se pode fazer a esse respeito é que, no exemplar retabular do templo luziense, esses itens substituíram os convencionais nichos dispostos nos tramos externos, destinados a acolher imagens devocionais.

Uma breve análise das peças retabulares luso-brasileiras, erguidas no século XVIII, esclarece que motivos afins constituíram, por exemplo, os retábulos de Nossa Senhora da Soledade e do Senhor Jesus Crucificado alocados na nave da igreja de São Miguel (Lisboa), e a talha parietal da igreja de São Francisco 
da Penitência (Rio de Janeiro), realizada pelo entalhador Manuel de Brito a partir do ano de 1739. ${ }^{38}$ Posteriormente, na década de 1790, o Aleijadinho empregou recursos semelhantes no plano ornamental que sequencia a composição do retábulo-mor da igreja de São Francisco de Assis (Ouro Preto). É inexato mapear as vinculações entre os medalhões do templo de Santa Luzia com os modelos arrolados, sobretudo porque não se pode presumir se o autor dessa traça conheceu os trabalhos lisboetas, as produções de Manuel de Brito no Rio de Janeiro ou se esboçou esse relevo a partir de referências gráficas extraídas de impressos circulantes à época. Do mesmo modo, é inviável anunciar se o espécime gizado e faturado pelo Aleijadinho para a igreja ouro-pretana de São Francisco serviu de espelho para a arte luziense, pois essa última foi faturada em momento anterior, encontrando-se finalizada em 1773. Todavia, são esses vestígios de que os ditos medalhões se fizeram presentes no vocabulário gráfico corrente no âmbito artístico do Barroco joanino e do Rococó, que também demarcaram a constituição formal do objeto retabular em estudo.

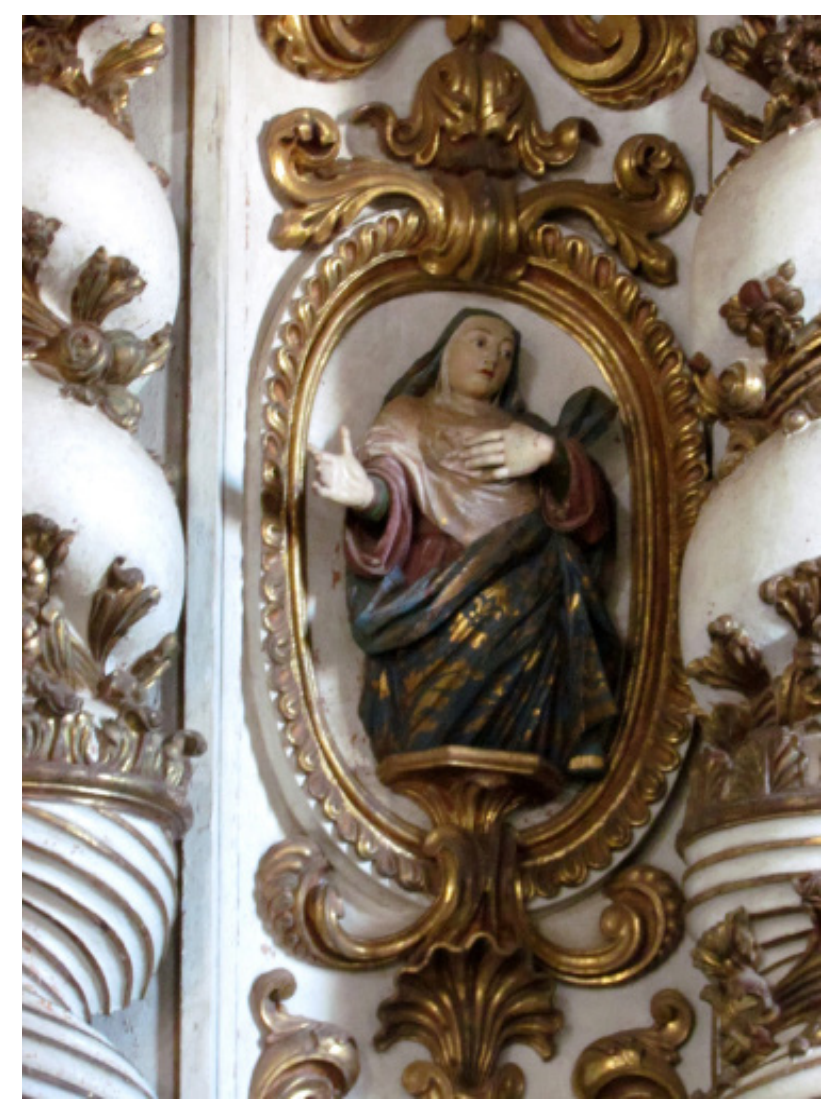

Figura 8 - Medalhão da Virgem Maria, retábulo-mor da Matriz de Santa Luzia, Santa Luzia (2017). Fotografia do autor. 
39. Ministério da Educação... (1951, p. 32).

40. Tavares (1975, p. 85).

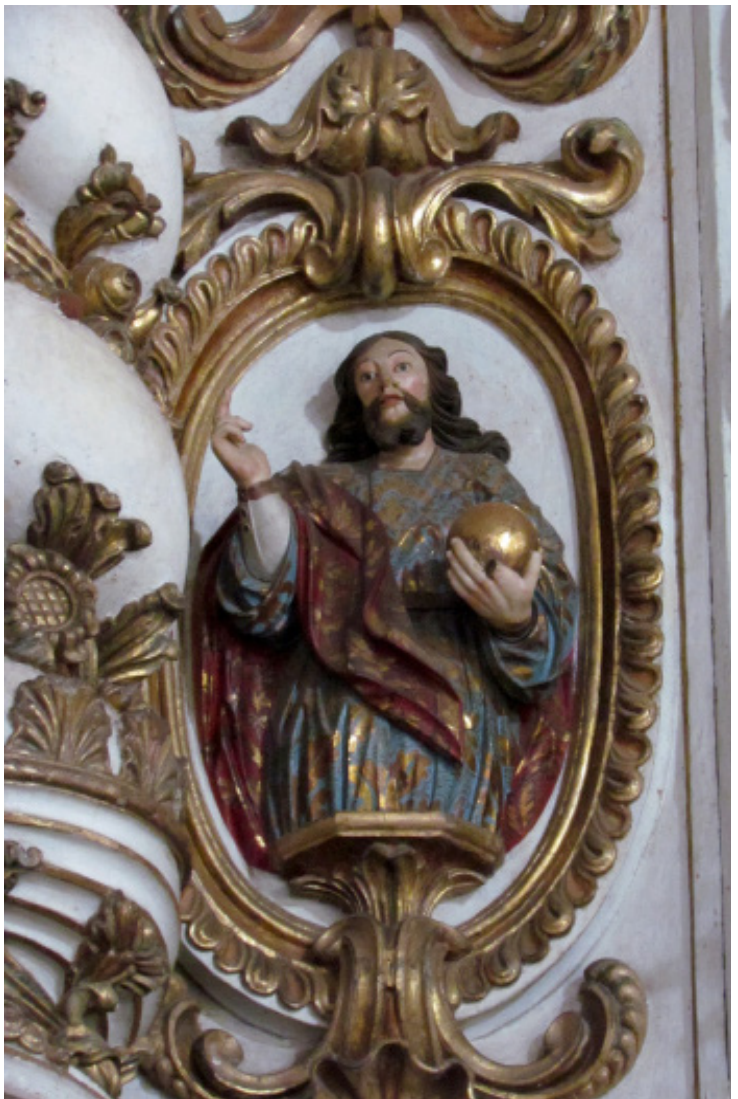

Figura 9 - Medalhão de São José, retábulo-mor da Matriz de Santa Luzia, Santa Luzia (2017). Fotografia do autor.

Para além das discussões empreendidas, deve-se relativizar que o prestígio principal desses medalhões, no contexto da talha mineira, é devido ao fato de que recai sobre um deles a suspeita de uma provável intervenção do Aleijadinho. Os apontamentos iniciais que permitiram a propagação desse senso foram interpostos por Rodrigo José Ferreira Bretas, ${ }^{39}$ quando distinguiu que o artista, na região de Santa Luzia, executou alguns serviços. Lamentavelmente, o autor não elucidou o local exato onde Antônio Francisco Lisboa exerceu sua arte, empecilho esse que dificulta a averiguação das notas proferidas. De posse dessa informação, a pesquisadora Myriam Ribeiro de Oliveira Tavares 40 reconheceu, em um desses relevos, aspectos que poderiam, supostamente, remeter ao modo do Aleijadinho delinear o rosto e as mãos das esculturas, sem, no entanto, pormenorizar análises suscetíveis de atestar o parecer emitido. 
Mesmo diante de estudos históricos inábeis a ratificar as proposições discorridas, não se pode aniquilar a expectativa de descobrir alguma obra oculta realizada pelo Aleijadinho na Matriz de Santa Luzia, que valide os registros emendados por Rodrigo José Ferreira Bretas. Entretanto, a necessidade de encontrar caminhos que permitam compreender o caso é ampliada neste artigo, a partir da introdução de uma segunda presunção interpretativa, que cogita a possibilidade de o relevo da Virgem, constante no retábulo-mor da Matriz de Santa Luzia, ser fruto da atividade do mesmo escultor que faturou as demais imagens que preenchem a referida peça retabular. Essa hipótese é alicerçada na existência de proximidades verificáveis nas figuras antropomórficas do sobredito retábulo e no relevo do medalhão em estudo, principalmente no formato de nariz, boca e olhos que elevam as afinidades entre essas obras e permitem mapear grupos de relações formais que insinuam a intervenção de um único artista, provavelmente contratado para lavrar todas as esculturas do conjunto. Essas conjecturas estabelecem questionamentos acerca da hipótese de que houve intervenção de Antônio Francisco Lisboa nesse objeto retabular. No entanto, a carência de documentação e de outras evidências que pontuem o labor do renomado artífice impõe que esse caso seja abordado com ressalvas, considerando-se que sua participação pode ter se restringido à materialização de imagens devocionais hoje desaparecidas, de algum objeto ornamental que não se encontra mais no interior da igreja ou, até mesmo, de serviço empreendido em outro templo situado na região do atual munícipio luziense.

Por sua vez, é legível que o medalhão de São José seja resultante da atividade do escultor que delineou as figuras antropomórficas instaladas no coroamento do retábulo-mor da Matriz de Santa Luzia (figura 10). Esse ponto de vista é sustentado pela permanência, no referido relevo, de aspectos comuns verificados nos desenhos de pescoço, boca, nariz, bigode saindo das narinas, barba finalizada em enrolamentos e cabelo partido ao meio, elementos que traduzem grupos de cacoetes abrangidos no repertório plástico de um mesmo artista, certamente envolvido na execução de ambos os serviços. É fundamental assinalar que o formato dos olhos e o desenho da porção inferior do nariz do São José são idênticos às feições que definiram as cabecinhas de anjos que ornam o registro do banco do retábulo-mor, incontestavelmente equivalentes às figuras antropomórficas que complementam a ornamentação do retábulo de São Miguel e Almas da Matriz de Nossa Senhora da Conceição, em Catas Altas. Esses indícios operam como testemunhas de que essas peças resguardam correspondências qualificadas a denotar o fazer de um mesmo artífice. 
41. Martins (1974, vol. 1, p.

379).

42. Ibid., vol. 1, p. 379.

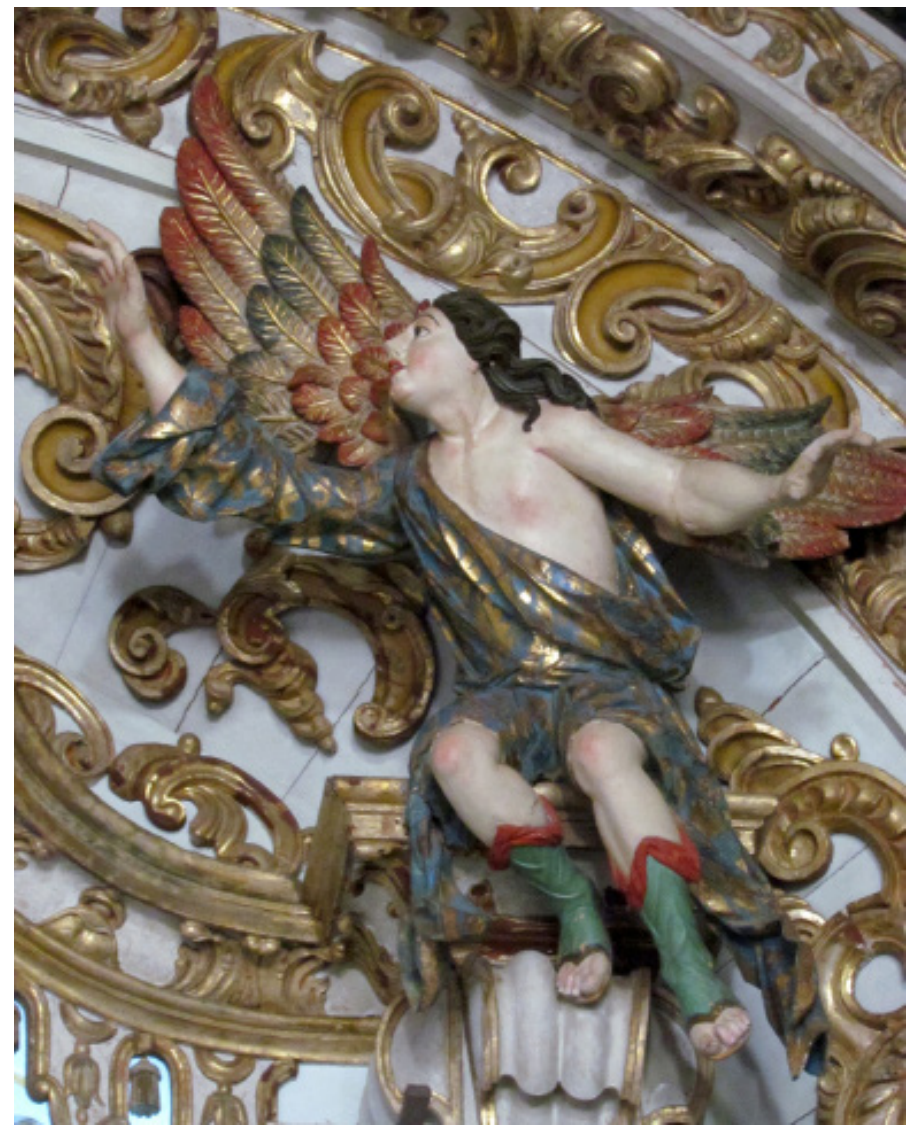

Figura 10 - Anjo do coroamento, retábulo-mor da Matriz de Santa Luzia, Santa Luzia (2017). Fotografia do autor.

Ressalvados esses aspectos, é inescusável discorrer sobre o artífice, ainda anônimo, encarregado pela execução das esculturas presentes no retábulo-mor da Matriz de Santa Luzia, examinadas nas linhas anteriores. No entanto, faz-se necessário explicitar, primeiramente, alguns pormenores que assinalaram a história da elevação do retábulo de São Miguel da Matriz de Nossa Senhora da Conceição (Catas Altas), uma vez que o entendimento desses fatos pode, eventualmente, sinalizar a identidade do oficial envolvido na fatura do retábulo-mor da igreja luziense.

Registros informam que, em 1744 - 1745, o entalhador Francisco Antônio Lisboa recebeu quantias pelo risco do retábulo de São Miguel. ${ }^{41}$ No intervalo entre 1745 e 1748, ele foi pago por serviços realizados na dita peça, não especificados. ${ }^{42}$ Para essa mesma empreitada, o entalhador Domingos Marques 
assinou documento, entre 1745 e 1751, atestando ter recebido valores designados como "serviços de talha". ${ }^{43}$ A documentação não esclarece 0 envolvimento de outros oficiais na execução do retábulo, mas é inteligível que Domingos Marques foi o nome central na oficina envolvida na concretização desse trabalho, posto que angariou avultados emolumentos em um período de, aproximadamente, cinco anos. Isso assevera a distinção de seu envolvimento na produção da obra em exame, em comparação à cooperação do autor do projeto, Francisco Antônio Lisboa, também encarregado pelo aparelhamento do retábulo de São Gonçalo, pertencente ao templo principal catas-altense. ${ }^{44}$

A inexistência de pesquisas sobre a atividade artística de Domingos Marques e de Francisco Antônio Lisboa dificulta o estudo de obras em que, arrazoase, eles possam ter operado. Logo, para produzir encaminhamentos que permitam elucidar a identidade do autor dos serviços realizados na Matriz de Nossa Senhora da Conceição (Catas Altas), confrontaram-se os elementos esculturais que compõem o retábulo de São Gonçalo da mesma igreja com os itens correlatos que adornam o trabalho de São Miguel e Almas, uma vez que Francisco Antônio Lisboa esteve envolvido na produção do primeiro, como detalha a documentação. ${ }^{45}$ Assim, seria essa a alternativa de investigação acessível para, em seguida, enumerar orientações acerca do possível autor das esculturas do exemplar da Matriz de Santa Luzia.

Surpreendentemente, esse exercício de observação propiciou constatar que não se reconhecem, em ambas as peças retabulares, aspectos aptos a denunciar a atividade de um mesmo artista, sobretudo na composição plástica das figuras antropomórficas, sempre esclarecedoras nessas situações, dado que nelas eram impressos traços da identidade de quem as esculpiu, traduzidos em marcas formais delimitadoras de seu fazer. Assim, o lançado exercício de Francisco Antônio Lisboa na obra do retábulo de São Miguel e São Gonçalo não é reconhecido no delineamento plástico da talha, visto que eles não apresentam feições símiles qualificadas a identificar uma autoria em comum.

silêncio dessa questão faz aflorar a suspeita de que Domingos Marques pode ter sido o autor das imagens que complementam o retábulo de São Miguel, pois é conhecida sua extensa atividade na confecção do conjunto, cerca de cinco anos, superando a intervenção de Francisco Antônio Lisboa que, inclusive, pode ter se restringido à confecção do projeto e de um ou outro elemento de talha, inabilitado a mapear os traços de sua arte. Caso essa hipótese seja confirmada por documentação ainda não identificada, poder-se-á admitir a possibilidade de ser Domingos Marques o oficial que realizou as esculturas do retábulo da supracitada igreja de Catas Altas.
43. Ibid., vol. 2, p. 25. 44. Ibid., vol. 1, p. 379. 45. Ibid., vol. 1, p. 379 . 
46. A pesquisadora Judith Martins assim denominou a ocupação de Lima Cerqueira, após amplo levantamento documental acerca de sua trajetória em Minas Gerais, entre os anos de 1761 e 1808. Ibid., vol. 1, p. 175179.

47. Oliveira (1956, p. 2).

48. Arquivo Eclesiástico do Arcebispado... (Prateleira Z-10, 1762, fl. 42v.).

49. Centro de Estudos... (1723-1798, vol. 132, fl. 63).

50. Pedrosa (2016, p. 204).

51. Arquivo Eclesiástico da Matriz... (1726-1805, fl. 175).
Todas essas averiguações sinalizam a pertinência das conjecturas processadas neste texto, quando se discorreu que o entalhador responsável por esculpir as figuras antropomórficas do retábulo-mor de Santa Luzia, enumeradas anteriormente, foi o mesmo que efetuou as imagens do retábulo de São Miguel e Almas do templo principal de Catas Altas. Ainda que a documentação não explicite seu nome, falha corriqueira no âmbito da produção da talha mineira, é admissível apreciar o pressuposto de ser ele, Domingos Marques, ativo na fábrica do espécime retabular da Matriz de Nossa Senhora da Conceição (Catas Altas), em que os vestígios identificadores de seu modo de definir a escultura em madeira poderiam ser estruturados com base no exame das peças debatidas e, principalmente, no retábulo catas-altense de São Miguel, onde ele trabalhou por longo tempo.

\section{FELIPE VIEIRA, FRANCISCO DE LIMA CERQUEIRA E A ARTE NA MATRIZ DE SANTA LUZIA: ALGUMAS CONSIDERAÇÕES SOBRE O TEMA}

As discussões empreendidas neste texto intuíram qualificar e compreender o retábulo-mor da igreja Matriz de Santa Luzia em associação ao contexto da talha setecentista mineira, apoiado nas observáveis relações detectadas nessa obra e em outros exemplares retabulares que, de algum modo, poderiam ter influenciado a formatação de sua estrutura e plástica. No entanto, é imperioso examinar a indicação do provável envolvimento do entalhador Felipe Vieira e do pedreiro e canteiro ${ }^{46}$ Francisco de Lima Cerqueira na produção desses serviços. Essas informações integram os relatos emendados por Tibúrcio de Oliveira, ${ }^{47}$ que arrolou esses homens como os responsáveis pela moldura e pelo entalhe do referido templo, sem, todavia, especificar quais foram os trabalhos por eles executados de fato, se realizados em sociedade ou separadamente.

Pouco se conhece sobre a vida e a atividade de Felipe Vieira. Sabe-se que era natural de Eira Vedra (Conselho de Viana, Arcebispado de Braga, Portugal). ${ }^{48}$ Entre os trabalhos por ele efetuados, destaca-se a obra do retábulo-mor da igreja de Santa Efigênia (Ouro Preto), arrematada juntamente com Jerônimo Felix Teixeira, em 1756, 49 aproximadamente. Nesse mesmo período, Vieira executou outros serviços em Minas, ${ }^{50}$ destacando-se sua participação, em 1763 e 1764, nos procedimentos de execução do retábulo-mor da igreja Matriz de Nossa Senhora da Conceição (Ouro Preto). ${ }^{51}$

O desconhecimento de outras obras produzidas por Felipe Vieira impede inspecionar e elencar, detalhadamente, os aspectos plásticos que nortearam a confecção de sua arte. As consequências desses infortúnios também impossibilitam 
que sejam apontadas, no retábulo-mor da Matriz de Santa Luzia, feições que mapeiem sua colaboração na execução da fatura da talha. Com certo esforço, distingue-se apenas o desenho do trono e de alguns ornatos dos degraus que podem, em hipótese, remeter a itens semelhantes presentes no retábulo principal da Matriz de Nossa Senhora da Conceição (Ouro Preto), onde a documentação comprova a atividade do entalhador. Ainda podem ser inseridos no rol dessas conjecturas os motivos curvilíneos em forma de " $C$ ", que ornam a renda da boca da tribuna do retábulo-mor da igreja de Santa Efigênia (Ouro Preto), semelhantes aos mesmos relevos que complementam o exemplar da Matriz de Santa Luzia. No entanto, é fundamental memorar que não se deve afirmar que tais arquétipos são fruto da atividade de um mesmo artífice, tampouco que eles foram realizados por Felipe Vieira, principalmente porque nenhuma outra associação é identificada entre outras peças por ele realizadas com o espécime luziense.

Ademais, salienta-se que Tibúrcio de Oliveira ${ }^{52}$ não explicitou, com clareza, qual foi a real participação de Francisco de Lima Cerqueira na produção da talha da Matriz de Santa Luzia, tampouco elencou detalhes que permitissem identificar o serviço que o artífice efetuou. A publicação organizada por Judith Martins ${ }^{53}$ notifica que o dito Cerqueira serviu como mestre pedreiro e canteiro, em prol da edificação de alguns templos religiosos mineiros, incluindo trabalhos nas igrejas de Nossa Senhora do Carmo (Ouro Preto) e de São Francisco de Assis (São João delRei). Não há, até o momento, vestígios que denotem seu exercício em tarefas correlacionadas ao trabalho da talha. Todavia, Germain Bazin ${ }^{54}$ e Myriam Oliveira ${ }^{55}$ apontam ser ele o provável oficial que interveio no risco primeiro para o retábulo-mor da igreja são-joanense de São Francisco de Assis, traçado pelo Aleijadinho, 56 cuja execução ficou a cargo do entalhador Luís Pinheiro de Sousa.

A teoria que circunda o tema, no que diz respeito à intervenção de Francisco de Lima Cerqueira no desenho da referida peça retabular, refere-se à existência de prova documental em que foi registrado ser ele o encarregado de procurar o arquiteto que elaborou o risco para a igreja são-joanense, Antônio Francisco Lisboa, também responsável pelo delineamento do projeto de talha para a capela-mor. ${ }^{57}$ Dentro dessas perspectivas, tanto Bazin 58 quanto Myriam Oliveira ${ }^{59}$ partilham a opinião de que o feitio do retábulo-mor de São Francisco pode ter sido alterado, posteriormente, por Francisco de Lima Cerqueira, ocasião essa em que ele inseriu, no conjunto, colunas de tipologia salomônica, cujas feições plásticas distanciam do contexto artístico cravado pelas influências do Rococó, que assinalaram o ciclo artístico no qual estava inserido o referido modelo retabular. Esse postulado é reforçado por meio do mapeamento das características norteadoras da estética dos retábulos concebidos ou riscados pelo
52. Oliveira (1956, p. 2).

53. Martins (1974, vol. 1, p. 175-179).

54. Bazin (1971, p. 309).

55. Oliveira (2003, p. 261).

56. Ministério da Educação... (1951, p. 60).

57. Martins (1974, vol. 1, p. 177).

58. Bazin (1971, p. 309).

59. Oliveira (2003, p. 261). 
60. Atestou Rodrigo José Ferreira Bretas, em 1858, que o Aleijadinho trabalhou "[...] em ermidas das fazendas da Serra Negra, Tabocas e Jaguara." Ministério da Educação... (1951, p. 32). Em publicação da Revista do Arquivo Público Mineiro, ano de 1906 , foram atribuídas ao artista as obras oriundas da antiga capela da Fazenda do Jaguara, hoje dispostas no interior da igreja Matriz de Nossa Senhora do Pilar, em Nova Lima. "A par d'essas preciosidades o templo mostra obras de talha algo preciosas, e, por muitos, atribuídas ao notável artista, que na legenda ou na história da arte-brasileira é designado pelo nome de Aleijadinho ao qual dam a paternidade de curiosos trabalhos em outras igrejas do Estado de Minas." Revista do Arquivo Público... (n. 11, v. 1, 1906, p. 585-597).

61. Bazin (1971, p. 309)

62. Oliveira (2003, p. 261).

63. Oliveira (1956, p. 2).

64. Martins (1974, vol. 1, p. 177).
Aleijadinho, cujos itens descritos não se relacionam a essa peça. Exemplifica esse caráter as colunas retas estriadas, vivamente presentes nos retábulos-mores da igreja de São Francisco de Assis (Ouro Preto) e da Matriz de Nossa Senhora do Pilar (Nova Lima), em que a talha é devida à atividade do Aleijadinho. ${ }^{60}$

Embora seja inexato precisar a sinalizada ałuação de Lima Cerqueira na obra do retábulo-mor da Matriz de Santa Luzia, pode-se, com base nas indicações deferidas por Bazin ${ }^{61}$ e Oliveira, ${ }^{62}$ especular ter sido ele o idealizador das colunas de tipologia salomônica que preenchem a peça retabular em foco. Essa conjectura é ancorada nas similaridades presentes entre os desenhos dessas colunas e as que se encontram no retábulo principal da igreja de São Francisco de Assis (São João del-Reil, que exibem idêntico formato do último terço, mesmo desenho das espiras e dos fustes. Entretanto, apesar de perceptíveis essas relações, cabe frisar que elas não são conclusivas e intentam, unicamente, detectar elementos que possam, por suposição, mapear a presumida atividade de Lima Cerqueira no exemplar luziense, em que o objeto artístico e os remanescentes documentais não estão habilitados a comprovar as elucubrações desenvolvidas por Tibúrcio de Oliveira. ${ }^{63}$

O distanciamento da provável intervenção de Francisco de Lima Cerqueira no retábulo-mor da Matriz de Santa Luzia e o conhecimento de que ele serviu como pedreiro, canteiro e arrematador de obras em que eram subcontratados oficiais para a execução das tarefas, como demarcam os procedimentos que balizaram a elevação do retábulo principal da igreja de São Francisco de Assis (São João del-Rei), ${ }^{64}$ impõem a necessidade de considerar uma segunda vertente para o entendimento desse evento, que tende a especular que Lima Cerqueira pode ter sido o arrematante da obra do retábulo-mor da Matriz de Santa Luzia, transferindo, posteriormente, a sua realização a uma oficina de entalhadores, destinada a materializar os serviços. Essas indagações visam, unicamente, interpor luzes sobre matéria de difícil desfecho.

\section{RETÁBULO DE NOSSA SENHORA DO ROSÁRIO E SÃO JOSÉ}

Assim como os demais elementos que complementam a ornamentação da Matriz de Santa Luzia, ainda são incógnitos os registros históricos referentes ao processo de produção do retábulo de Nossa Senhora do Rosário (figura 111) a data em que foi erigido e a oficina envolvida nesse empreendimento. Portanto, resta ao pesquisador o exame do objeto artístico que, de certo modo, imputa formulações de hipóteses que intentam situá-lo no cenário artístico colonial luso-mineiro. 
Desse modo, observa-se que os ornamentos integrantes da dita peça rementem às frequentes escolhas delimitadoras da talha mineira dos setecentos, em que o registro do banco de planta côncava recebeu pares de mísulas envolvendo meninos, cartelas emolduradas por ornatos curvilíneos e fitomórficos, palmeta e relevo de mascarão. Na região central, o sacrário engloba mísulas, enrolamentos, porta com cruz, relevos fitomórficos com meninos e conchas no arremate. Destacase que figuras semelhantes de mascarões foram itens recorrentes na escultura ornamental retabular vinculada ao Estilo Nacional, ${ }^{65}$ como bem ilustra a configuração formal do retábulo da igreja de Nossa Senhora do Ó (Sabará). Posteriormente, esses relevos desapareceram das obras atreladas ao estilo joanino.
65. O Estilo Nacional português manifestou-se na talha em Minas a partir dos anos finais do século XVII e do despontar do século XVIII, perdurando a manutenção de seus ornamentos e estruturação formal até por volta da década de 1730. O pesquisador Alex Fernandes Bohrer analisou as obras de talha mineiras que abrigam características do Estilo Nacional. Cf. Bohrer (2015).

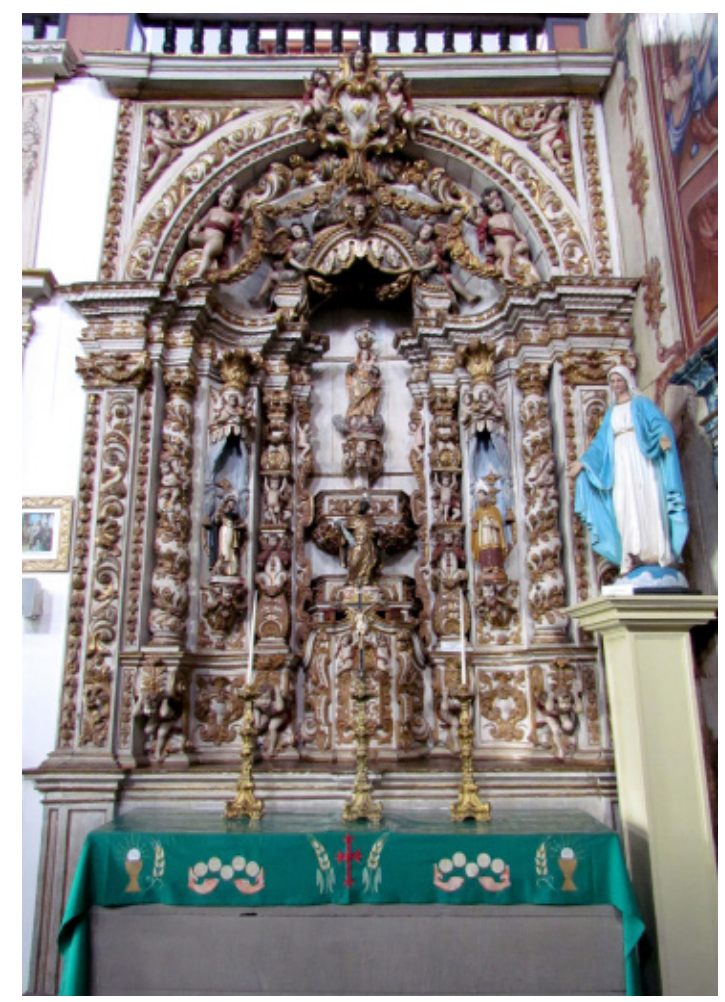

Figura 11 - Retábulo de Nossa Senhora do Rosário, Matriz de Santa Luzia, Santa Luzia (2017). Fotografia do autor.

A seção do corpo retabular recebeu, externamente, pilastras retas emolduradas com pendão de botões de flores, motivos fitomórficos e curvilíneos. Internamente, foram instaladas colunas torsas com esculturas de meninos e, ladeando o camarim, interessantes elementos de sustentação definidos por cabecinhas de anjos e esculturas triplas de meninos. No intercolúnio, o nicho, 
66. Centro de Estudos... (1723-1798, vol. 132). uma peanha com cabecinha de anjo e a cúpula superior em dossel com lambrequins, anjos na porção superior e palmeta no arremate. $\bigcirc$ camarim é desprovido de talha, que parece ter sido eliminada em data incerta. Na renda da boca da tribuna, ornatos fitomórficos e meninos.

coroamento é defino por arco pleno inserido em frontão retilíneo, englobando colunas laterais com botões de flores e dossel central com lambrequins e cortinados suspensos por esculturas de anjos. Nas laterais, anjos sentados sobre enrolamentos seguram o festão de flores que remetem ao mesmo ornato que se encontra na parede do camarim do retábulo-mor. Há, também, tarja com relevo indicando a devoção à Senhora do Rosário, ladeada por enrolamentos, ramos de flores e cabecinha de anjo no arremate.

A interpretação dos arquétipos formais e estruturais definidores desse retábulo, frente aos modelos que constituíram a talha em Minas Gerais no século XVIII, permite apontar que ele foi executado entre 1735 e 1750, quando, inicialmente, foram assimiladas as manifestações plásticas do estilo joanino na então capitania mineira. Caracteriza as amostras desse ciclo o recorrente uso de dossel com cortinados no coroamento, acentuando as feições teatrais que demarcaram trabalhos coevos luso-brasileiros. No registro do corpo, colunas torsas com folhagem e esculturas de meninos reafirmam o caráter da arte do período. Para esse caso, é fundamental indicar as relações do exemplar luziense com os retábulos de Santa Rita e de Nossa Senhora do Carmo, presentes na igreja de Santa Efigênia (Ouro Preto), gizados e faturados por Francisco Branco de Barros Barrigua entre 1746 e 1748,66 que outorgaram estipular a presumível data de confecção da obra em exame, da Matriz de Santa Luzia, que, por sua vez, também apresenta paridades com a de São José dos Bem Casados, da Matriz de Nossa Senhora da Conceição (Ouro Preto).

Por seu turno, no retábulo de Santo Antônio da Matriz ouro-pretana de Nossa Senhora da Conceição, há colunas homônimas às que ladeiam o camarim do retábulo da Senhora do Rosário do templo de Santa Luzia, guarnecidas por três meninos na porção superior do elemento estrutural, cujos aspectos escultóricos e vestimentas também estreitam as relações de igualdade entre essas peças. $\bigcirc$ elevado número de figuras antropomórficas distribuídas pela composição é mais uma característica que pontua esse ciclo da talha joanina mineira. Não se pode inferir terem sido essas obras resultantes do labor de uma mesma oficina, devido à ausência de documentação e de aspectos que comprovem, incontestavelmente, essa prerrogativa. Entretanto, não é improvável pensar que o entalhador que se envolveu nessa produção da igreja de Santa Luzia tivesse conhecimento da obra 
retabular dedicada a Santo Antônio, bem como a de São Miguel, da Matriz de Nossa Senhora da Conceição, onde essas configurações são encontradas.

Além disso, devido ao caráter da constituição formal do retábulo de Nossa Senhora do Rosário, é consistente considerar a possibilidade de essa ser uma obra procedente de algum antigo templo da região de Santa Luzia, reaproveitada na atual matriz, reerguida na década de 1740. Tais hipóteses são alimentadas pela constatação de que a remontagem deixou incompletas a composição de alguns registros e tramos, como as regiões do camarim e do coroamento, que não omitem se tratar de adaptação realizada ulteriormente ao momento da fábrica das peças. A policromia desse modelo retabular também pode ter sido produzida ou refeita em outro período, distante da data de sua fatura, devido às semelhanças com exemplares da época rococó.

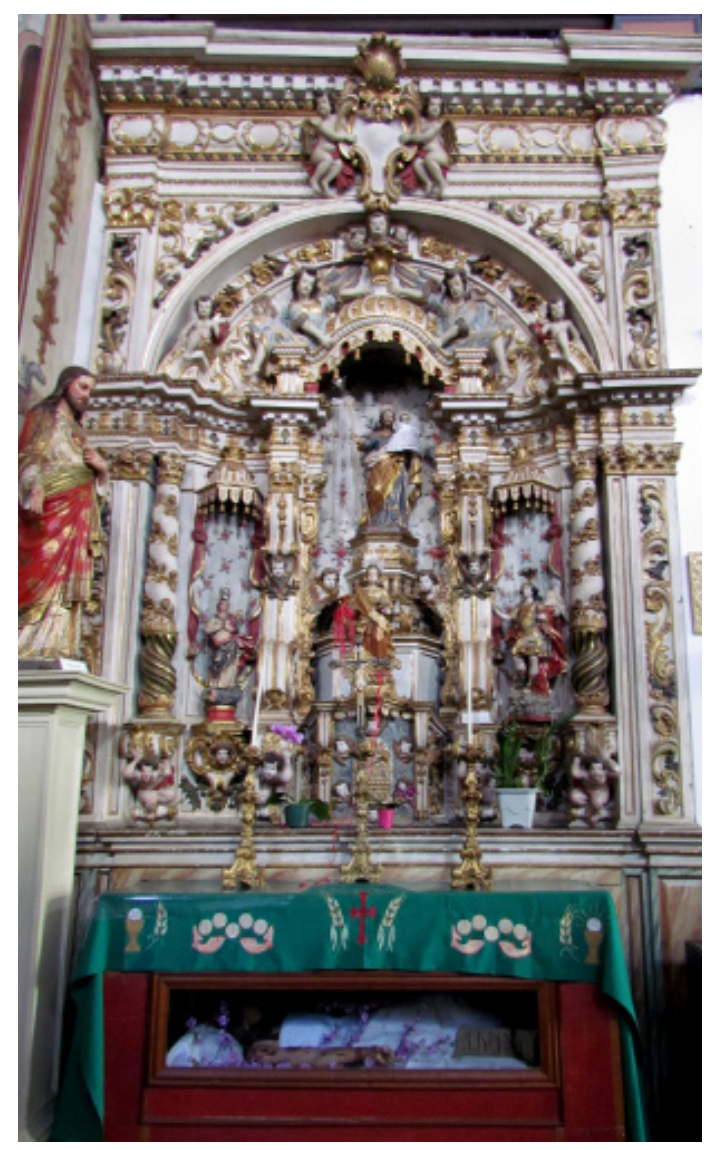

Figura 12 - Retábulo de São José, Matriz de Santa Luzia, Santa Luzia (2017). Fotografia do autor. 
Por último, deve-se relativizar a presença do retábulo dedicado a São José, da Matriz de Santa Luzia, cuja base foi ornada com pequenas molduras, limitando a pintura que imita marmorizado (figura 12). O banco é composto por pares de mísulas com meninos, cartelas com motivos curvilíneos e sacrário animado por cabecinhas de anjos envolvidas em nuvens, que circundam o relevo do cordeiro deitado sobre Livro dos Sete Selos.

A sustentação é assegurada por pilastras retas laterais ornadas com motivos curvilíneos e folhagens, colunas de tipologia salomônica e quartelões que ladeiam o camarim. No intercolúnio, observam-se peanhas, cortinado, dossel com lambrequins e palmeta na porção superior. No camarim, renda da boca da tribuna com ornatos fitomórficos, curvilíneos, cabecinhas de anjos e o trono escalonado em degraus.

Sequencialmente, o coroamento em arco pleno e inserido em frontão retangular com dossel central. Figuras antropomórficas aladas, sentadas sobre mísulas tríplices, ladeiam esse elemento. Nas laterais, foram alocados meninos sentados sobre fragmento de frontão curvo. Buquês de flores e outros itens fitomórficos compõem o registro. $\bigcirc$ frontão, que abrange o coroamento, foi finalizado com arquitrave, friso e cornija denticulada. Em sua região central está uma tarja emoldurada por ornatos curvilíneos e arrematada por palmeta.

A estrutura, os ornamentos e os aspectos estilísticos do retábulo de São José são condizentes às tendências do estilo joanino, correntes na talha mineira entre 1730 e 1760, em que o corpo retabular, costumeiramente, recebeu colunas de tipologia salomônica e quartelões, intercalados por nichos. No coroamento do dossel, ladeado por figuras antropomórficas, também se evidenciam as influências estéticas joaninas que nortearam a produção dessa peça, ainda que nessa região estejam presentes relevos assimétricos prenunciadores do Rococó, que despontaria na talha local após 1760.

\section{CONSIDERAÇÕES FINAIS}

O desconhecimento de registros passíveis de elencar as datas e os atores responsáveis pelo desenho e pela fatura dos retábulos da Matriz de Santa Luzia, examinados neste texto, demandou a aplicação de ferramentas que possibilitassem situá-los no contexto da talha colonial luso-mineira. Para tanto, foi necessário confrontar os itens ornamentais e as feições estéticas que compõem esses retábulos com outros modelos que resguardam aspectos similares. Por esse viés, especula- 
se, sem conclusões definitivas, o momento em que foram produzidas essas obras em discussão e as prováveis influências advindas de espécimes pertencentes a templos religiosos localizados em cidades ao redor de Santa Luzia. Essa abordagem metodológica permitiu constatar que o risco para o retábulo-mor luziense, de autor anônimo, pode ter sido subsidiado em memórias visuais provenientes dos retábulos-mores das igrejas Matriz de Nossa Senhora do Bom Sucesso (Caeté) e Matriz de Nossa Senhora da Conceição (Catas Altas).

Apoiado nessa ilação, conseguiu-se estimar, aproximadamente, as datas em que foram materializados os três exemplares em debate. Esse entendimento está subvencionado pelos estudos organizados por Aziz Pedrosa, ${ }^{67}$ autor que deslindou a instauração e o transcorrer da estética joanina na talha em Minas Gerais, durante o século XVIII. Nesse sentido, presume-se que o retábulo de Nossa Senhora do Rosário tenha sido confeccionado entre as décadas de 1730 e 1750, cuja estrutura e ornamentos se vinculam aos modelos existentes nas igrejas ouro-pretanas de Santa Efigênia, retábulos laterais de Santa Rita e Nossa Senhora do Carmo, e da Matriz de Nossa Senhora da Conceição, retábulos laterais de São José dos Bem Casados, São Miguel e Santo Antônio.

Por sua vez, a arte do retábulo de São José pode ser inserida no ciclo final da ascendência do estilo joanino na talha mineira, em estágio de assimilação das tendências advindas do Rococó. Mesmo que seja ímprobo estabelecer uma data, poder-se-ia cogitar se tratar de peça produzida entre 1745 e 1755, considerando-se o desenho do dossel e a composição estrutural assegurada por colunas de tipologia salomônica e quartelões, que dialogam com demais espécimes desse ciclo, sobretudo com alguns retábulos laterais da Matriz de Nossa Senhora da Conceição, em Catas Altas.

Na referenciada obra de São José, desperta a atenção os nichos ladeando o coroamento, compostos por dosséis quadrados, equivalentes àqueles constantes nas obras erguidas ou que contaram com intervenções do entalhador José Coelho de Noronha, pontuados nos retábulos-mores das igrejas Matriz de Nossa Senhora do Pilar (Ouro Preto), Matriz de Nossa Senhora do Pilar (São João del-Rei) e Matriz de Nossa Senhora do Bom Sucesso (Caeté). ${ }^{68}$ A permanência dessas relações explana, mais uma vez, que os retábulos do templo de Santa Luzia podem ter propagado referências assimiladas de obras expostas nas edificações sacras ao redor da região de Santa Luzia, conquanto não seja factível sinalizar se esses eventos sejam quocientes da influência de um ou de outro entalhador.

Quanto ao retábulo-mor, é crível que ele tenha sido confeccionado entre 1760 e princípios de 1770, haja vista os registros revelarem que sua fatura 
estava concluída em 1773. Os arquétipos ornamentais e estilísticos denunciam ser esse um exemplar influenciado pela estética joanina, com predominância da assimilação do Rococó. Salienta-se que essas e outras apreciações tiveram como eixo norteador a fundamental influência absorvida de outros objetos retabulares, que podem ter inspirado o autor do risco. É nesse espectro que se encontra imersa a intervenção do entalhador que laborou na produção do retábulo de São Miguel, da Matriz de Nossa Senhora da Conceição /Catas Altas), cujos indícios anunciam a hipótese de ser o desconhecido Domingos Marques, ao qual está atrelada a ideia de ser este o oficial encarregado de executar as esculturas antropomórficas do retábulo-mor luziense.

Em meio aos deferimentos realizados, é substancial memorar que a concretização desta pesquisa, sem o respaldo de documentação, deixa hiatos e respostas que não explicaram a indicada operação de Felipe Vieira e Francisco de Lima Cerqueira na execução de talha para a capela-mor da Matriz de Santa Luzia. Deve-se recordar que os indícios encontrados não sustentam uma avaliação indubitável, tampouco corroboram para desenhar direções habilitadas a demarcar uma possível atribuição de autoria. Nesse sentido, reforça-se que as discussões emendadas acerca da matéria tiveram como intuito, especificamente, argumentar as indicações deferidas por Tibúrcio de Oliveira ${ }^{69}$ e, assim, encontrar elementos que possam clarificar ideias que são, de fato, repletas de incertezas. Logo, é de interesse que venha a público documento capaz de narrar a trajetória histórica dos retábulos da igreja Matriz de Santa Luzia, benéfico para o enriquecimento da história da arte colonial em Minas Gerais, demasiadamente carente de estudos.

Por fim, mais uma vez, registra-se que este artigo propôs trazer à discussão fragmentos sobre a arte e a história dos retábulos da igreja Matriz de Santa Luzia, não privilegiados nos debates realizados pela crítica de arte. Logo, acredita-se que esse momento inicial seja capaz de amparar investigações futuras determinadas a construir novos conhecimentos sobre as obras analisadas, a fim de esboçar um renovado panorama para o estudo da talha em Minas e, assim, esclarecer as omissões que o autor deste artigo não soube deslindar. 


\section{REFERÊNCIAS}

FONTES MANUSCRITAS

ARQUIVO DA PARÓQUIA DE NOSSA SENHORA DO PILAR. Livro de Termos da Irmandade do Santíssimo Sacramento, 1729-1777, vol. 224.

ARQUIVO ECLESIÁSTICO DA MATRIZ DE NOSSA SENHORA DA CONCEIÇÃO DE ANTÔNIO DIAS. Livro de Receitas e Despesas da Irmandade de Nossa Senhora da Conceição, 1726-1805.

ARQUIVO ECLESIÁSTICO DO ARCEBISPADO DE MARIANA. Livro de Devassas. Prateleira Z-10, 1762.

ARQUIVO PÚBliCO MINEIRO. Seção Colonial, Delegacia Fiscal, códice 1075. Belo Horizonte, [s. d.].

CENTRO DE ESTUDOS DO CICLO DO OURO. Livro de Receitas e Despesas da Irmandade do Rosário dos Pretos de Ouro Preto, 1723-1798, vol. 132.

\section{FONTES IMPRESSAS}

N. B. Succinta descripção da Fazenda do Jaguara no Estado de Minas Geraes. Revista do Arquivo Público Mineiro, Edição Imprensa Oficial de Minas Gerais, n. 11, v. 1, p. 585-597, 1906.

OLIVEIRA, Tibúrcio de. Templo de fé e sentinela da liberdade comemora mais de duzentos anos a mais histórica Matriz de Minas Gerais: Relíquias do Passado. Jornal Estado De Minas, Belo Horizonte, dia 9 de dezembro do ano de 1956, p. 2. (Jornal localizado nos Arquivos do Instituto do Patrimônio Histórico e Artístico Nacional - IPHAN - Belo Horizonte, Minas Gerais, pasta referente à igreja Matriz de Santa Luzia).

LIVROS, ARTIGOS E TESES

ÁVILA, Affonso; GONTIJO, João Marcos Machado; MACHADO, Reinaldo Guedes; FUNDAÇÃO JOÃO PINHEIRO. Barroco mineiro: glossário de arquitetura e ornamentação. Belo Horizonte: Fundação João Pinheiro, 1996. 
BAZIN, Germain. O Aleijadinho e a escultura barroca no Brasil. Rio de Janeiro: Record, 1971.

BOHRER, Alex Fernandes. A Talha do Estilo Nacional Português em Minas Gerais: contexto sociocultural e produção artística. 2015. 2 vol. Tese (Doutorado em História) - FAFICH, Universidade Federal de Minas Gerais, Belo Horizonte, 2015.

COSTA, Antônio Gilberto. Rochas e Histórias do Patrimônio Cultural do Brasil e de Minas. Rio de Janeiro: Bem-te-vi, 2009.

HILL, Marcos Cesar de Senna. Le sculpteur Francisco Xavier de Brito: état de la question et analyse de son oeuvre de la chapelle de la 'Penitência de São Francisco' de Rio de Janeiro. 2 vol. Tese (Livre docência) - Université Catholique de Louvain, Louvain, 1990.

MARTINS, Judith. Dicionário de artistas e artífices dos séculos XVIII e XIX em Minas Gerais. 2 vols. Rio de Janeiro, Ministério de Educação e Cultura, 1974. Publicações do Instituto do Património Histórico e Artístico Nacional, v. 27.

MATEUS, Adalberto Andrade. Santa Luzia: atos de proteção - bens culturais tombados. Santa Luzia: Edição do Autor, 2016.

MENEZES, Ivo Porto de. Manuel Francisco de Araújo. Revista do Patrimônio Histórico e Artístico Nacional, Rio de Janeiro, n. 18, p. 83-113, 1978.

MINISTÉRIO DA EDUCAÇÃO E SAÚDE. Antônio Francisco Lisboa: o Aleijadinho. Rio de Janeiro: MEC/DPHAN, 1951 (Publicações da Diretoria do Patrimônio Histórico e Artístico Nacional, n.15).

OLIVEIRA, Myriam Andrade Ribeiro de. O Rococó religioso no Brasil e seus antecedentes europeus. São Paulo: Cosac e Naify, 2003.

PEDROSA, Aziz José de Oliveira. José Coelho de Noronha: artes e ofício nas Minas Gerais do século XVIII. 2012. 303 f. Dissertação (Mestrado) - Escola de Arquitetura e Urbanismo, Universidade Federal de Minas Gerais, Belo Horizonte, 2012.

PEDROSA, Aziz José de Oliveira. A produção da talha joanina na capitania de Minas Gerais: retábulos, entalhadores e oficinas. 2016. 591 f. Tese (Doutorado) - Escola de Arquitetura, Universidade Federal de Minas Gerais, Belo Horizonte, 2016.

PEDROSA, Aziz José de Oliveira. Modelos, formas e referências para os retábulos em Minas Gerais: o caso do tratado de Andrea Pozzo. Revista Historia Autónoma, n. 13, p. 103-124, 2018. 
POZZO, Andrea. Perspectiva pictorum et architectorum Andreae Putei e societate Jesu. Pars seconda, In quâ proponitur modus expeditiffimus delineandi opticè omnia, quae pertinent ad Architecturam. Romae MDCCLVIII, Ex apud Joannem Generosum Salomoni. Typographum, et Bibliopolam. Praesidum Facultate.

SANTIAGO, Camila Fernanda Guimarães. Uso e impacto de impressos europeus na configuração do universo pictórico mineiro (1777-1830). 2009. 383 f. Tese (Doutorado) -Faculdade de Filosofia e Ciências Humanas, Universidade Federal de Minas Gerais, Belo Horizonte, 2009.

SILVA, Mateus Alves. O tratado de Andrea Pozzo e a pintura de perspectiva em Minas Gerais. 2012. 164 f. Dissertação (Mestrado) - Faculdade de Filosofia e Ciências Humanas, Universidade Federal de Minas Gerais, Belo Horizonte, 2012.

SMITH, Robert C. A talha em Portugal. Lisboa: Livros Horizontes, 1962.

TAVARES, Myriam Ribeiro de Oliveira. In: Igreja Matriz de Santa Luzia do Rio das Velhas: informe histórico - artístico. In: Processo de Tombamento - Santa Luzia Sede - Basílica de Santa Luzia do Rio das Velhas (PTE 043). Belo Horizonte: Instituto Estadual do Patrimônio Histórico e Artístico de Minas Gerais, 1975.

TRINDADE, Raimundo (Cônego). Instituição de Igrejas no Bispado de Mariana. Rio de Janeiro: MEC/SPHAN, n.13, 1945.

Artigo apresentado em 08/08/2018. Aprovado em 20/03/2019.

\section{(cc) BY}

All the contents of this journal, except where otherwise noted, is licensed under a Creative Commons Attribution License 